\title{
Boulezova racionalna serialna organizacija in Cageovo naključje - enakost različnega
}

\author{
Boulez's rational serial organization and \\ Cage's chance - equality of diversity
}

Ključne besede: Pierre Boulez, John Cage, serialnost, naključje, zvočni rezultat

POVZETEK

Konec druge svetovne vojne je mogoče razumeti tudi kot pomembno estetsko ločnico v zgodovini novejše svetovne glasbe. Nestabilna duhovna klima, ki je bila prežeta $z$ groznimi spomini na pravkar končano vojno in strahom pred nejasno prihodnostjo, ter dolgoletni izolacija in diskontinuiteta glasbenega življenja so omogočili in narekovali generaciji mladih skladateljev, da do temlja spremenijo tradicionalni glasbeni "jezik". Pri tem so sicer izhajali iz Schönbergove dvanajsttonske tehnike, vendar pa so osnovno idejo - ureditev vseh dvanajstih poltonov oktave $\mathrm{v}$ vrsto - prenesli še na druge parametre zvoka (ritmične dolžine, dinamika, artikulacija). Tako je Pierre Boulez leta 1951 s skladbo Structures Ia za dva klavirja udejanil zamisel o homogeni serialni strukturi, v kateri so vrste za posemezne parametre zvoka urejene tabelarno, njihovo distribucijo pa kontrolirajo "nadvrste , izpeljane iz osnovnih vrst. Istega leta je
Key words: Pierre Boulez, John Cage, serial music, chance operations, acoustic realisation

SUMMARY

The end of the Second World War can be understood as an important aesthetic dividing point in the history of modern music. The unstable spiritual climate, imbued with dreadful recollections of the just finished war, pervaded with the fear of a vague future, together with lengthy isolation and the discontinuity of musical life, enabled and dictated the young generation of composers to a radical change of traditional musical "language". They were influenced from Schönberg's twelvetone technique, but they applied the central idea, the arrangement of all twelve semitones of an octave in one row, also on other parameters of sound (rhythmic values, dynamics, articulation). In 1951 Pierre Boulez wrote his composition Structures Ia for two pianos in which he realized the idea of homogeneous serial structure. The series for separate parameters of sound were arranged in tabular form, their distribution was 
tabelarno uredil glasbeni material za svojo skladbo Music of Changes tudi John Cage, ki je prek korespondence Boulezu sploh prvi nakazal možnost tabelarnega urejanja materiala za vse parametre zvoka. Vendar pa Cage ni izbral nadvrst in se je namesto racionalni sistematiki pri distribuciji izbranega materiala $\mathrm{z}$ metom kovancev že prepustil naključju. Tako sta paradoksalno prav skladbi, v katerih sta si skladatelja za izhodišče izbrala zelo podoben koncept, pripeljali do popolne ločitve, po kateri Bouleza in Cagea povezujemo $\mathrm{z}$ dvema navidez diametralno nasprotnima tokovoma $v$ glasbi po drugi svetovni vojni: serialnostjo in aleatoriko. Vendar pa nam analizi zvočnih rezultatov obeh skladb dajeta zelo podobne rezultate, kar postavlja prizadevanja obeh skladateljev iz začetka petdesetih let 20. stoletja $\mathrm{v}$ povsem novo luč in jima daje posebno dokumentarno vrednost. V obeh primerih lahko namrec slišimo vrsto med seboj nepovezanih tonov, razpršenih v širokem ambitusu, brez razločnega metričnega impulza, $\mathrm{v}$ konstantnem, kontrastnem menjavanju dinamike. Zato analiza ne more več iskati melodije, harmonije, urejenega ritmičnometričnega pulza, motivično-tematskega dela ali klasične formalne gradnje; glasbeni stavek je veliko bolj odvisen od fizikalnih parametrov zvoka in njihovega spreminjanja (gostota teksture, povprečna jakost in frekvenca zvoka, število dogodkov na časovno enoto). Tako obe skladbi pričata o posebnem stanju glasbenega materiala in kompozicijske tehnike po drugi svetovni vojni in o skupni želji po vzpostavitvi povsem novega glasbenega "jezika". however controlled with "super-series", derived from the basic series. In the same year John Cage also organized the musical material for his composition Music of Changes in tabular form. He was actually the first who indicated the possibility of organizing the material for all parameters of sound in separate tabulated lists. Yet he did not select any "super-series" and instead of the distribution of organized musical material of rational systematics he chose assigned by the tossing of three coins. Thus, two compositions for which both composers selected very similar basic concepts led paradoxically to complete separation, so that Boulez and Cage are usually connected with two seemingly diametrical opposite streams of music after the Second World War: serial and aleatoric music. The analyses of the final acoustic realizations of both compositions give us however very similar results, which throws a new light on the efforts of both composers from the beginning of the ' 50 s of the 20th century and gives them a special documentary value. In both cases, we hear a variety of mutual unconnected tones, spread over a wide tone-range, without distinct metrical impulse in a constant and contrasting change of dynamics. Therefore, the analysis should not be concentrated on the melody, harmony, regular rhythmical-metrical pulse, motivic-thematic work or classical formal construction; musical texture depends much more on the physical parameters of sound and their change (density, average volume and frequency, and number of musical events in a time unit). In this way, both compositions bear witness to a special state of music material and compositional technique after the Second World War and share the common desire for developing a new musical "language".

Duhovna zgodovina nas uči, ${ }^{1}$ da pomembne zgodovinske zareze večkrat prerastejo tudi v ostre estetske ločnice. Najgloblja zareza preteklega 20. stoletja je bila gotovo druga svetovna vojna, posledice katere niso bile le številne človeške žrtve in ogromna materialna škoda, temveč tudi negotovost in strah ljudi, ki so morali svoje življenje pričenjati na novo. Evforijo ob končani vojni je skalil strah pred nejasno prihodnostjo. Taka nestabilna duhovna klima je svoje globoke sledi pustila tudi v umetnosti, ki je dobila $\mathrm{v}$ povojnih razmerah povsem novo vlogo. V času, ko je bila glavna skrb namenjena golemu preživetju, se je zdelo nesmiselno ukvarjati se $s$ kompleksnimi estetskimi vprašanjimi, temu pa se je pridužila še dilema, kako se spopasti s preteklostjo in tradicijo, 
nad katero je ležala bridka izkušnja hitrega vzpona nacizma in fašizma. Zato sta postali osrednji vprašanji mlade generacije umetnikov, kako se navezati na preteklost in jo evolucijsko nadaljevati ter kako začeti na novo. Reševanje tega problema je še dodatno oteževalo dejstvo, da skladatelji sploh niso dobro poznali glasbe svojega časa, kar je bila posledica dolgoletne izolacije in izvajalske diskontinuitete. Tako so skladbe, ki so jih zdaj "odkrivali" in so jim zvenela "novo" (npr. dela P. Hindemitha), nastale že na začetku tridesetih let. Povojna umetnost se je zaradi tega znašla na "točki nič", ${ }^{2}$ ki je omogočala radikalni prelom s "starim" in popolnoma nov začetek.

Vendar pa se je bilo treba kljub veliki želji po novem, ki naj bi tudi simbolično prekinilo s svetom, ki je zanetil dve strašni svetovni vojni, najprej spoznati z vsem, kar je nastalo v času vojne in iz nje izhajajoče kulturne izolacije. Tega se je zavedal tudi snovalec darmstadtskih poletnih tečajev za Novo glasbo Wolfgang Steinecke. Tako se je mlada generacija nemških skladateljêv v Darmstadtu najprej spoznala z deli skladateljev starejše generacije (P. Hindemith, I. Stravinski, B. Bartók). Steinecke pa s svojimi tečaji ni želel doseči le plodne izmenjave med mladimi in starimi, temveč tudi med domačimi in tujimi skladatelji. ${ }^{3}$ Tako darmstadtska poletna šola kmalu ni bila vpeta zgolj v nemški kontekst seznanjanja $z$ deli, nastalimi v času dvanajstletne izolacije, temveč je dobila mednarodni pečat. V tem smislu je bil še posebej pomemben prihod Renéja Leibowitza, vodilnega evropskega poznavalca Schönbergove dodekafonske tehnike, ki je v Darmstadtu predaval leta 1948. Takoj po vojni namreč v Evropi ni nikogar zanimala Schönbergova glasba, saj je veljala za preživeto (nekoliko drugače je bilo v ZDA, kjer si je Schönberg pridobil ugled kot profesor kompozicije). Do pravega spoznanja njegove glasbe in kompozicijske tehnike je prišlo šele s posredovanjem Leibowitza v Darmstadtu, ${ }^{4}$ čemur je sledila še vrsta izvedb njegovih del in del njegovih najslavnejših učencev: Antona Weberna in Albana Berga. Posledica tega je bila, da so se morali mladi skladatelji zdaj aktivno opredeliti do dodekafonske tehnike: mnogi so jo tudi sprejeli, kar je sprožilo spremembo recepcije del, napisanih v dvanajsttonski tehniki. Ta se namreč sploh niso več zdela radikalno moderna tako kot pred vojno, temveč so šla vštric $s$ tistimi skladbami, ki so iskala vezi v tradiciji. S tem je bila prva naloga darmstadtskih tečajev - seznanjanje $s$ preteklo glasbo - končana in pred vrati je bilo novo obdobje, v katerem so skladatelji začutili praznino "točke nič"; nov svet, zgrajen iz pepela druge svetovne vojne, je potreboval tudi novo glasbo, pri čemer so skušali nadaljevati tam, kjer je končal Schönberg, ki je s svojimi inovacijami med prvimi pričel sistematično razbijati tonalnost. Za ta čas je tako značilna izjava Pierra Bouleza, da so morali po vojni začeti znova, ker njihovi predhodniki niso prinesli prave revolucije, saj niso spoznali vseh implikacij, ki jih prinaša ukinjanje tonalnosti. ${ }^{5}$

Kako se je "gradil" nov glasbeni jezik po drugi svetovni vojni, je najbolj zanimivo preučevati prav na primeru opusa Pierra Bouleza in njegovega ameriškega sodobnika

\footnotetext{
Prim.: Ralf Schnell, «Nullpunkt», Umbruch oder Kontinuität, v: Deutsche Literaturgeschichte, Stuttgart 1992, str. 435-448 in Hans Vogt, Neue Musik, Stuttgart 1972.

Prim.: Wolfgang Steinecke, Kranichstein - Geschichte, Idee, Ergebnisse, v: Darmstädter Beiträge zur Neuen Musik, Mainz 1961.

Prim.: Ulrich Dibelius, Moderne Musik 1945-1965, München 1966.

Prim.: Robert P. Morgan, Twentieth-Century Music, New York, London 1991.
} 
Johna Cagea. Danes se zdi, da bi si bilo težje izbrati še kak bolj diametralno nasproten skladateljski par: Bouleza povezujemo z začetki serializma, radikalnim modernizmom in strogo zahodnoevropsko miselnostjo, ujeto v racionalnost, Cagea pa razumemo kot očeta glasbe "naključja in predstavnika glasbene avantgarde, ki je ideje za svoja glasbena dela črpal predvsem iz vzhodnjaške filozofije (indijska filozofija, zen budizem), mistike Meistra Eckharta in socioloških misli M. McLuhana in B. Fullerja. Bolj nasprotujoče si duhovne podlage si skoraj ni mogoče zamisliti, vendar je - kakor bo razvidno iz nadaljevanja - vsaj na začetku oba vodila ista želja: vzpostavitev povsem novega glasbenega jezika brez zvez s tonalnostjo.

Prva dela Pierra Bouleza so še pod močnim vplivom njegovega profesorja za analizo na pariškem konservatoriju Oliviera Messiaena (npr. Trois psalmodies), vendar pa ga učiteljev slog očitno ni zadovoljil, saj naj bi bil zgolj produkt eklekticizma in nebrzdanega eksotizma. ${ }^{6}$ Leta 1945 je slišal prva dvanajsttonska dela, kar je v njem prebudilo željo po študiju pri Renéju Leibowitzu, vendar mu tudi ta pouk in obvladovanje dodekafonije nista prinesla pravih rešitev. Prepričal se je celo, da je Schönberg storil usodno napako, ko se je odločil, da bo dvanajsttonsko tehniko apliciral na klasičnih oblikah. ${ }^{7}$ Zato je v resnici prinesel le delni napredek, saj se ni zavedal pravih daljnosežnosti svojega odkritja. Njegova retorika je ostala stara, saj ni spoznal, da nova organizacija materiala zahteva tudi novo morfologijo, sintakso in retoriko. Boulez je šel celo tako daleč, da je v naslovu svojega članka iz leta 1952 zapisal Schönberg est mort - Schönberg je mrtev. Bil je trdno prepričan, da je po odkritju dvanajsttonske tehnike, ki omogoča nadzor nad tonskimi višinami, treba najti tudi "atonalni ritmični element ${ }^{9}$. Kot možen izhod je predlagal nekakšno združitev odkritij druge dunajske šole $z$ ritmičnimi inovacijami Stravinskega in Messiaena. Iskal je torej jasno podlago za nov glasbeni jezik, logično pot, univerzalno tehniko, $s$ katero bi lahko poenotil osnovne konstituente glasbe - tonske višine, trajanja, jakost, zvočno barvo. Prizadeval si je za metodo, način organizacije glasbenega materiala, ki bi zagotavljal notranjo konsistenco glasbenega dela in enotnost glasbene strukture. Zato ni čudno, da mu je kot izhodišče služila sicer Messiaenova nedodekafonska skladba Mode de valeurs et d'intensités, v kateri je vseh šestintrideset poltonov treh oktav zvezanih z natančno določenim registrom, ritmično vrednostjo, dinamiko in artikulacijo. Messiaenovo idejo je nadgradil v prvi izmed struktur za dva klavirja - Structures Ia-in tako ustvaril popolnoma serialno delo s totalno organizacijo. ${ }^{10}$

Istočasno je do podobnih spoznanj prišel tudi trinajst let starejši John Cage. Pri tem ne gre prezreti dejstva, da je po nasvetu svojega učitelja Henryja Cowella ${ }^{11}$ med letoma

\footnotetext{
Prim.: Theo Hirsbrunner, Pierre Boulez und sein Werk, Laaber 1985.

Pierre Boulez, Relevés d'apprenti, Paris 1966, str. 270.

Pierre Boulez, Schönberg est mort, v: The Score, Februar 1952.

Prim.: Pascal Decroupet, Renverser la vapeur..., v: Heinz-Klaus Metzger, Rainer Riehn (ur.), Pierre Boulez, München 1995, str 112 .

10 Pozorni moramo biti na pomensko razločevanje naslednjih terminov: dodekafonija oz. dvanajststonska tehnika je princip, pri katerem je v vrsto urejena le zaloga dvanajstih poltonov oktave, o serialni glasbi lahko govorimo takrat, ko je na podoben način urejenih več parametrov zvoka, s totalno organizacijo pa lahko označimo tiste serialne skladbe, $v$ katerih so vrste za posamezne parametre zvoka med seboj organsko povezane in izmenljive ali pa neka nadrejena vrsta določa celotno formalno podobo skladbe.

11 Prim.: John Cage, Über frühere Stücke, v: Richard Kostelanetz, John Cage, Köln 1973, str. 178-185.
} 
1935 in 1937 obiskoval ure kontrapunkta in analize pri takrat v ZDA že slavnem Schönbergu. Leto poprej je napisal Sonato za dva glasova, Skladbo za tri glasove in Solo z obligatno spremljavo, v katerih se je ukvarjal z možnostjo kromatične ureditve vseh petindvajsetih poltonov dveh oktav. Gre za mehanična, polifona dela, skladatelj pa v njih ni predpisal niti inštrumentov, niti dinamike ali fraziranja, kar le še poudarja hladno konstrukcijo. Na takšno organizacijo je gotovo vplivala Schönbergova dodekafonija, vendar je Cage prevzel le idejo o enakovrednosti vseh poltonov oktave, ne pa tudi urejevanja le-teh v vrste. Schönberg je Cageu tudi očital, da nima smisla za harmonijo, ${ }^{12}$ česar se je mladi skladatelj očitno zavedal, saj je naslednjih petnajst let pisal predvsem skladbe, $v$ katerih je razvijal ritmično komponento, ${ }^{13}$ obenem pa je širil glasbeni material in pri tem poudarjal, da lahko prav vsak zvok postane glasba, saj so zvoki med seboj enakovredni. ${ }^{14}$ Prepričan je bil, da bo na mesto "starega nasprotja med disonanco in konsonanco zdaj stopilo razmerje med hrupom in t.i. glasbenimi zvoki ${ }^{15}$ Skladatelj bo tako postal "organizator zvoka" in stari principi, ki so skladateljem nekaj stoletij omogočali strukturiranje skladb - predvsem harmonija -, ne bodo več uporabni. Razviti bo potrebno nov kompozicijski sistem, za katerega pa Cage ne dvomi, "da bo gotovo povezan s Schönbergovo dvanajsttonsko tehniko ${ }^{16}$ Izguba tonalnosti torej zahteva nov pripomoček za strukturiranje glasbenih del in Cage meni, da harmonijo lahko zamenja ritem oz. čas. Potrdilo za to je našel v dejstvu, da med vsemi parametri zvoka (frekvenca, trajanje, jakost, barva) le trajanje določa tako zvoke kot tišino, torej celoten glasbeni material. ${ }^{17}$

V sklop prizadevanj za enakovrednost vseh zvokov in šumov sodi Cageov naslednji "izum" - preparirani klavir. Na strune inštrumenta in med njih je postavljal različne kovinske in gumijaste predmete (žeblji, kovanci, radirke...) ter $s$ tem primarno melodični in harmonski inštrument spremenil v veliko in raznoliko tolkalo. Prvo skladbo za preparirani klavir - Bacchanale - je napisal že leta 1940, vse možnosti takega inštrumenta pa je najbolje izkoristil devet let kasneje v Sonatas E Interludes. Prav z izvedbami te skladbe je postal v ZDA priznan skladatelj. Prejel je Guggenheimovo štipendijo, kar mu je omogočilo, da je odpotoval v Pariz, kjer je proučeval Satiejeva dela in se seznanil s sodobno evropsko glasbo. Še posebej pomembno je bilo, da se je v Parizu srečal $z$ mladim Boulezom. Skladatelja sta se takoj spoprijateljila, saj v svoji okolici očitno nista imela drugih dovolj zanimivih sogovornikov. V Parizu je Boulez živel skoraj v nekakšni glasbeni izolaciji, saj v krogu njegovih prijateljev ni bilo nobenega glasbenika, zato je ves

12 Prim.: R. Kostelanetz, John Cage, str. 81.

13 V opusu iz tega časa izstopajo dela za tolkala brez določene tonske višine. Tako Cage nima opravka s harmonijo ali melodijo in to dejstvo ga sili, da išče novo ritmično organizacijo svojih skladb. Nov princip ritmičnega strukturiranja, ki posega tako v makro-kot tudi mikroritmično organizacijo, pri čemer si je glasbeno strukturo predstavljal kot nekakšen prazen zaboj, ki ga je moč z matematično metodo razdeliti in nato zapolniti z zvoki oz. tišino, je prvič uporabil v skladbi First Construction (in Metal) iz leta 1939, ki v celoti temelji na razmerju 4:3:2:3:4. Skladba ima pet delov, ki so med seboj v razmerju 4:3:2:3:4, to razmerje pa določa tudi organizacijo znotraj delov. Tako sestoji prvi del iz štirih enot, vsaka od teh enot pa je sestavljena iz niza po $4,3,2,3$ in 4 takte (skupaj ima prvi del torej $4 \times(4+3+2+3+4)$ taktov), drugi del iz treh takih enot, tretji iz dveh, četrti iz treh in peti ponovno iz štirih. Skupno ima cela skladba $4 \times(4+3+2+3+4)+3 \times(4+3+2+3+4)+2 \times(4+3+2+3+4)+3 \times(4+3+2+3+4)$ $+4 \times(4+3+2+3+4)$ taktov, ali če poenostavimo $(4+3+2+3+4) \times(4+3+2+3+4)$ oz. $16^{2}$.

14 John Cage, The Future of Music: Credo, v: isti, Silence, Cambridge, Massachusetts in London ${ }^{4} 1970$, str. 4.

15 Prav tam

16 Pravtam, str. 5.

17 Prim.: John Cage, Forerunners of Modern Music, v: J. Cage, Silence, str. 62-66. 
čas ponavljal, da se v Parizu nič ne dogaja. ${ }^{18}$ Podobno je ugotavljal Cage tudi za New York, kjer da "nihče nima nobene ideje ${ }^{19}$ Duhovna osamljenost je umetnika tesno povezala in oba sta se zanimala za delo drugega.

Junija 1949 je Cage izvajal Sonatas \& Interludesv salonu znamenite mecenke Suzanne Tézena. Za to priložnost je Boulez napisal razlago Cageovega dela ${ }^{20} \mathrm{v}$ kateri izpostavlja Cageove novosti, obenem pa predstavi že tudi vse osrednje ideje, za uresničitev katerih se sam bori ves čas. Tako ugotavlja, da postavlja Cage $z$ zvoki, ki jih dobi $s$ preparacijo klavirja, pod vprašaj sprejete akustične norme, ki jih nima več za definitivne. Prav zato si želi ustanovitve posebnega centra za eksperimentalno glasbo, v katerem bi se lahko posvečali nadaljnjemu raziskovanju zvokov in širjenju akustične sprejemljivosti. $^{21}$ Namesto čistih tonov uporablja Cage zvočne agregate in iz prepariranega klavirja izvablja "kompleksne frekvence». To pa se povezuje tudi z zavrnitvijo tradicionalnega harmonskega sistema. Prav zato naj bi Cage potreboval urejevalni princip, ki bi mu omogočal jasnejše strukturiranje skladb. Novo ritmično strukturo je utemeljil s "čisto formalno, neosebno idejo “, ${ }^{22}$ ki se kaže v obliki številčnih razmerij. Na področju ritma naj bi tako vpeljal metodò, ki omogoča prelom s tradicijo, kar se nenavadno ujema $z$ Boulezovo željo po novih ritmičnih organizacijah, ki naj bi bile na nek način še povezane s Schönbergovo dodekafonijo.

Oba skladatelja sta torej prepričana, da je Schönberg z dodekafonijo prinesel pomembno spremembo, vendar pa svojega načrta ni uresničil dosledno, saj je z novo metodo organiziral le tonske višine, ne pa ostalih "parametrov zvoka", medtem ko je formalne postopke prevzel iz tradicije. Zato ju druži želja po popolnoma novi glasbeni strukturi in drugačni zvočni podobi. To potrjuje Cageovo veselje ob skladanju dela String Quartet in Four Parts, saj naj bi mu delo $Z$ "lestvico zvokov" omogočilo, ${ }^{23}$ da v skladbi ne bi bilo več mogoče ločiti kontrapunkta in harmonije. ${ }^{24}$ Dualnost med vertikalo in horizontalo pa želi izničiti tudi Boulez, ki v enem izmed pisem sporoča Cageu, da bo tudi sam uporabljal zvočne agregate ( $L e$ soleil des eaux). ${ }^{25}$ Prav delo s kompleksi zvočnih frekvenc je Bouleza napeljalo, da je pričel dvomiti o zvokovnem materialu, ki ga je do zdaj uporabljal. ${ }^{26}$

Kljub dvomom, kateri zvočni material naj uporablja, pa je Boulezu popolnoma jasno, da je lahko le-ta "organiziran samo serialno" ${ }^{27}$ Tako se posveča "popolni ekspanziji in homogenosti na področju serializma ${ }^{28}$ Serialno metodo želi prenesti na vse parametre zvoka, serialni principi pa naj določajo tudi formalne elemente. Serialno metodo primerja s funkcijami v matematiki, saj je serijo, ki določa tonske višine (dvanajsttonska vrsta) moč razumeti tudi kot funkcijo frekvence ( $f($ frekvenca)), isto funkcijo pa je zdaj mogoče

18 Prim.: Jean-Jacques Nattiez, The Boulez-Cage Correspondence, Cambridge 1993, str. 33.

19 Prav tam, str. 50.

20 Prav tam, str. 27-32.

21 Leta 1974 je z ustanovitvijo inštituta IRCAM tudi uresničil Cageovo idejo o eksperimentalnem centru za sodobno glasbo.

22 J.-J. Nattiez, The Boulez-Cage Correspondence, str. 31.

23 V celem kvartetu Cage poljubno kombinira le 33 glasbenih elementov, ki jih je predhodno izbral in uredil v lestvico.

24 Prim.: J.-J. Nattiez, The Boulez-Cage Correspondence, str. 55.

25 Prim.: prav tam, str. 85.

26 Prim.: prav tam, str. 45.

27 Prav tam, str. 86.

28 Prav tam, str. 99. 
prenesti tudi na druge parametre zvoka - na primer na čas in dinamiko ( $f$ (čas), $f($ dinamika $){ }^{29}$ Menjajo se torej spremenljivke in ne funkcije, tako da je celotno serialno strukturo matematično moč opredeliti kot množico s funkcijami za posamezne parametre zvoka kot elementi: $\psi=\{f$ (frekvenca), $f$ (čas), $f$ (dinamika), $f$ (artikulacija) $\} .^{30}$ Prav s serialno organizacijo se skladatelj osvobodi pojmov, kot so melodija, harmonija in kontrapunkt. $^{31}$ Ne ukvarja se več $z$ vertikalo in horizontalo, pač pa urejuje dve koordinati: frekvenco in trajanje, to pa sta akustična fenomena.

Homogeno serialno strukturo (gl. opombo 30) je Boulez dosledno udejanil v svoji skladbi Structures Ia iz leta 1951. Izbral je dvanajsttonsko vrsto in jo označil s številkami od 1 do 12, isto oštevilčenje (tako da npr. ton fis vedno nosi številko 6 in ton a 3) pa je ohranil tudi za označevanje inverzije. S pomočjo takega oštevilčenja posameznih tonov vrste je sestavil dve tabeli z vsemi možnimi dvanajstimi transpozicijami osnovne vrste in njene inverzije. ${ }^{32} \mathrm{~V}$ vodoravne vrste je zapisal transpozicije, ki si v kolonah vrstijo po zaporedju tonov osnovne vrste na tonu es (tako v prvi tabeli osnovni vrsti na začetnem tonu es sledijo transpozicije na $d$, $a$, as itd.).

Iz obeh tabel je možno prebrati vseh 48 variant dvanajsttonske vrste $(12 \times \mathrm{O}, 12 \times \mathrm{I}$, $12 \times \mathrm{RO}, 12 \times \mathrm{RI}),{ }^{33}$ saj pri branju vsake vrste $\mathrm{v}$ tabeli iz desne proti leve dobimo rakove obrate osnovne vrste (prva tabela) oz. rakove inverzije (druga tabela).

Z obema tabelama pa si je Boulez pomagal tudi pri določevanju ritmičnih vrst, serij dinamike in serij artikulacij. Izbral je vrsto ritmičnih dolžin, ki jo sestavlja dvanajst elementov, pri čemer je vsak naslednji večji od prejšnjega za dvaintridesetinko, ta pa je obenem tudi izhodiščna vrednost. Zaporedje je spet označeno s številkami od 1 do 12, ki povedo, koliko dvaintridesetink traja posamezna ritmična enota. Tako označevanje Boulezu omogoča, da tudi ritmično vrsto poveže z obema tabelama transpozicij in na ta način izbira različne ritmične permutacije. Zanimivo je, da se v svoji zasnovi dvanajsttonska in ritmična vrsta bistveno razlikujeta, saj je slednja oblikovana kot aritmetično zaporedje (n, 2n, 3n..., pri čemer je vrednost n enaka dolžini dvaintridesetinke), dvanajsttonska vrsta pa je svobodnejša, brez kake simetrične urejenosti. Vseeno pa dvanajsttonska vrsta tudi $z$ različnimi transpozicijami (intervali ostajajo enaki, spremeni se le absolutna tonska višina elementov vrste) ne spreminja svojih glavnih značilnosti, ritmična vrsta pa doživlja velike spremembe (prim. zaporedje v prvi tabeli v vrsti $\mathrm{O}_{\mathrm{es}}$ in zaporedje $\mathrm{RI}_{\text {cis }} \mathrm{v}$ isti tabeli). Obe tabeli se v primeru dvanajsttonskih vrst obnašata kot tabeli transpozicij in v primeru ritmičnih vrst kot tabeli različnih permutacij.

Kot "aritmetično" zaporedje je zasnovana tudi vrsta dinamike, saj je vsaka naslednja vrednost nekoliko višja od prejšnje:

29 Prim.: pravtam, str. 102.

30 Boulez loči dve serialni strukturi: če se funkcijo za en parameter zvoka lahko prenese še na druge parametre, govorimo o homogeni serialni strukturi, $v$ primeru ko pa so serijske funkcije zvezane le s posameznimi parametri, je pred nami heterogena serialna struktura. Torej lahko govorimo o totalni organizaciji v primeru homogene serialne strukture - gl. opombo 10 (prim.: J.-J. Nattiez, The Boulez-Cage Correspondence, str. 102).

31 Prim.: J.-J. Nattiez, The Boulez-Cage Correspondence, str. 103.

32 Gl. György Ligeti, Pierre Boulez. Decision and Automaticism in Structure Ia, v: Die Reihe 3, Bryn Mawr 1959, str. 38 ali Ctirad Kohoutek, Tehnika komponovanja u muzici XX veka, Beograd 1984, str. 148.

33 Štiri osnovne verzije dvanajsttonske vrste označujemo na naslednji način: $\mathrm{O}$ - originalna vrsta, RO - rakov obrat originalne vrste, I - inverzija, RI - rakova inverzija. Mala črka ob označbi tipa vrste nam pove, na katerem tonu se vrsta začenja. 


$\begin{array}{llllllllllll}1 & 2 & 3 & 4 & 5 & 6 & 7 & 8 & 9 & 10 & 11 & 12 \\ \text { pppp } & p p p & p p & p & \text { quasi } p & m p & m f & \text { quasif } & f & f f & f f f & f f f f\end{array}$

Tudi to vrsto je Boulez označil s številkami, kar mu ponovno omogoča povezavo s transpozicijskima tabelama. Permutacij dinamičnih vrednosti pa ni priredil številčnim zaporedjem posameznih tranpozicij, temveč si je pomagal z diagonalami:

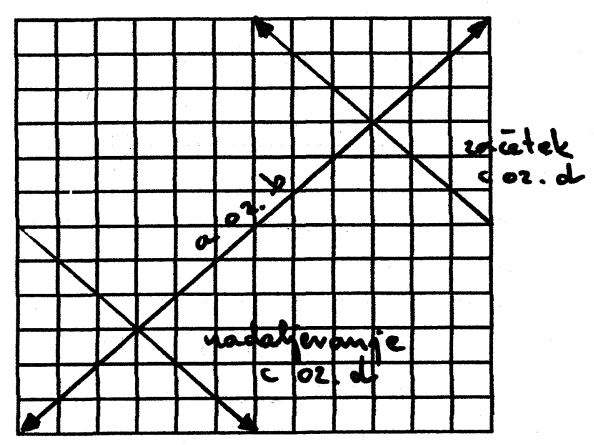

Tako je dobil štiri permutacije osnovne vrste: vrsti $\mathbf{a}(12-7-7-11-11-7-7-12)$ in $\mathbf{c}(2-3-$ 1-6-9-7-7-9-6-1-3-2) je prebral iz tabele s transpozicijami osnovnih vrst oz. njenih rakovih obratov na način, kot ga ponazarja zgornji primer (puščica nakazuje smer branja številčnega zaporedja) ter analogno vrsti b (5-2-2-8-8-12-12-8-8-2-2-5) in d (7-3-1-9-62-2-6-9-1-3-7) iz tabele s transpozicijami inverzij oz. rakovih inverzij. Značilno je, da so te štiri vrste simetrične (drugi del je zrcalna slika prvega, zato je njihova rakova inverzija identična osnovni), $v$ njih pa se dva elementa (4-p in 10-ff) sploh ne pojavita. Tako $\mathrm{v}$ skladbi v resnici uporablja le deset dinamičnih oznak, prav tako pa je tudi $z$ različnimi artikulacijami, saj je tudi za te uporabil "diagonalno branje " transpozicijskih tabel. Ponovno je dobil štiri vrste: $\alpha$ (5-5-11-3-12-11-3-12-8-1-8-1) in $\gamma$ (6-6-2-2-6-6-9-1-5-5-1-9) je prebral iz tabele s transpozicijami osnovnih vrst ter $\beta$ (12-12-8-3-5-8-3-5-11-1-11-1) in $\delta$ (6-1-12-12-1-6-9-9-7-7-9-9) iz tabele s transpozicijami inverzij. V teh zaporedjih manjkata zopet števili 4 in 10 - osnovna vrsta artikulacij ima tako le deșet elementov:

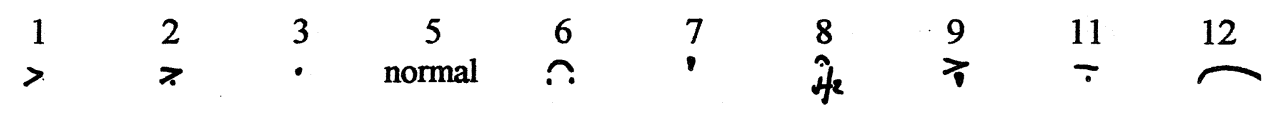

Boulez je torej najprej izbral osnovno gradivo za skladbo in ga že tudi uredil. Celotno skladbo je tako gradil z 48 variantami dvanajsttonskih vrst (po 12 transpozicij osnovne vrste, rakovega obrata osnovne vrste, inverzij in rakovih inverzij), 48 permutacijami osnovne aritmetične vrste ritmičnih vrednosti, 4 permutacijami dinamičnih vrednosti in 4 permutacijami načinov artikulacije. Takoj nas zbode v oči razmerje števila vrst tonskih višin in ritmičnih permutacij nasproti številu permutacij dinamičnih vrednosti in načinov artikulacije-48:4. To je povezano z Boulezovo odločitvijo, da se bodo tonske višine in trajanja spreminjala $z$ 
vsako noto, medtem ko bo celo vrsto (12 tonskih višin v povezavi $z 12$ različnimi ritmičnimi vrednostmi) zaznamovala enotna dinamika oz. način artikulacije.

Na podoben način je glasbeni material izbral in uredil že O. Messiaen v svoji skladbi Mode de valeurs et d'intensités, a Boulez je napravil še korak naprej. Če Messiaen še svobodno izbira v množici jasno organiziranega materiala, Boulez racionalno določi tudi načine izbiranja in kombiniranja le-tega. Tako nad posameznimi serijami (tonske višine, trajanja, dinamika, artikulacija) bdi še nadrejena serija, ki kontrolira njihov potek in spajanje. Dvanajsttonska vrsta $v$ povezavi z ritmično permutacijo in določenima konstantnima dinamiko in artikulacijo tvori serijski niz. ${ }^{34}$ Celotna skladba je zgrajena kot preplet takih nizov, pri čemer Boulez vsako varianto dvanajsttonske vrste (48) uporabi le enkrat. Ti nizi lahko potekajo istočasno, ne da bi se med seboj križali, saj je trajanje vseh nizov enako (vsaka ritmična vrsta je le permutacija osnovne, ki traja 78 dvaintridesetink: $1 \times \boldsymbol{F}+2 \times \boldsymbol{F}+3 \times \boldsymbol{F}+\ldots+12 \times \boldsymbol{F})$. V partu vsakega od obeh klavirjev potekajo po dva ali trije nizi istočasno, na dveh mestih (med 24. in 31. ter med 57. in 64. taktom) pa izvaja en klavir le en niz, drugi klavir pa sploh nobenega. Tako se gostota nizov v skladbi spreminja od ena do šest.

Ker je vsak niz enako dolg in ker se tudi vsi začenjajo skupaj, se skladba jasno deli v kratke odseke - teh je 14, v njih pa se razvrsti 48 serijskih nizov (od enega do prepleta šestih):

\begin{tabular}{l|l|l|l|l|l|l|l|l||l|l|l|l|l|l} 
odsek & $I$ & ${ }^{I I}$ & ${ }^{I I I}$ & $I V$ & $V$ & $V I$ & $V I I$ & $V I I$ & $I X$ & $X$ & $X I$ & $X I I$ & $X I I$ & $X I V$ \\
\hline takti & $1-7$ & $8-15$ & $16-23$ & $24-29$ & $\begin{array}{l}30- \\
39\end{array}$ & $\begin{array}{l}40- \\
47\end{array}$ & $\begin{array}{l}48- \\
56\end{array}$ & $\begin{array}{l}57- \\
64\end{array}$ & $\begin{array}{l}65- \\
72\end{array}$ & $73-81$ & $\begin{array}{l}82- \\
89\end{array}$ & $\begin{array}{l}90- \\
97\end{array}$ & $\begin{array}{l}98- \\
105\end{array}$ & $\begin{array}{l}106- \\
115\end{array}$ \\
\hline $\begin{array}{l}\text { število } \\
\text { nizov }\end{array}$ & 2 & 4 & 3 & 1 & 6 & 2 & 5 & 1 & 5 & 3 & 4 & 4 & 2 & 6 \\
\hline del & & & & & & & & & & & & & \\
\hline
\end{tabular}

Višja organizacija materiala se torej nanaša tako na vertikalno (porazdelitev nizov med oba klavirja) kot tudi na horizontalno os (zaporedje nizov v vsakem izmed klavirjev). Ker se po štiriindvajsetih nizih (to ni sredina skladbe, saj se $\mathbf{A}$ del konča $z$ VIII. odsekom v 64. taktu, kar govori o tem, da je v $\mathbf{B}$ delu večja povprečna gostota nizov) spremeni način kombiniranja serij v nize, lahko skladbo razdelimo na dva dela: $\mathbf{A}$ in $\mathbf{B}$. Makroorganizacija skladbe je jasno premišljena, saj si dvanajsttonakse vrste in ritmične permutacije ter spremembe dinamike in artikulacije sledijo po v naprej določenem vrstnem redu. Trdnost principa razkriva že število nizov v obeh delih, razporejenih med oba klavirja. Tako se v A delu v prvem klavirju zvrsti 12 nizov, enako tudi v $\mathbf{B}$ delu, isto razporeditev pa je zaslediti tudi v partu drugega klavirja - torej po 12 nizov v $\mathbf{A}$ in $\mathbf{B}$ delu. Že sama številka 12 nam govori, da so tudi sami nizi podrejeni serijski kontroli. In res: $\mathrm{V}$ prvem klavirju se v A delu zvrsti vseh 12 transpozicij originalne dvanajsttonske vrste najprej originalna vrsta na tonu es, potem na tonih $e, a, b, h, c, d, f$, fis, as (=gis), cis in

34 Izraz je posnet iz natančne Ligetijeve razlage tega Boulezovega dela (prim.: G. Ligeti, Pierre Boulez. Decision and Automatism in Structure Ia). 
kot zadnja na tonu $g$. Če te začetne note razumemo kot novo dvanajsttonsko vrsto in jo $s$ pomočjo znanega oštevilčenja pretvorimo v številčno zaporedje, dobimo naslednjo vrsto: 1-7-3-10-12-9-2-11-6-4-8-5. To je moč najti v obeh transpozicijskih tabelah; gre za inverzijo osnovne vrste na tonu es $\left(\mathrm{I}_{\mathrm{es}}\right)$. Iz tega sledi, da so začetni toni dvanajsttonskih vrst in s tem zbir vseh originalov tonskih vrst v partu prvega klavirja v A delu urejeni kot inverzija na tonu es. Podobne principe srečamo tudi v ureditvi ostalih šestintridesetih dvanajsttonskih vrst pa tudi v organizaciji drugih parametrov zvoka.

Tako je Boulez med oba klavirja razvrstil vseh možnih 48 oblik dvanajsttonskih vrst. Te pa je vsakič povezal še z eno izmed 48 permutacij osnovne vrste ritmičnih vrednosti, ki jih je najti v obeh transpozicijskih tabelah. V partu prvega klavirja je v A delu na primer zbir vseh originalnih dvanajsttonskih vrst povezan z zbirom vseh rakovih inverzij ritmičnih permutacij, urejenih kot rakova inverzija na tonu $h$, in v B delu zbir vseh rakovih inverzij dvanajsttonskih vrst $\mathrm{z}$ zbirom inverzij ritmičnih permutacij, urejenih kot rakov obrat originalne vrste na tonu $h$.

Ker se dinamika in način artikulacije ne spreminjata $z$ vsako noto, pač pa šele $z$ vsako novo dvanajsttonsko serijo, ne moremo iskati nadrejene organizacije, temveč lahko le ugotovimo, kako je Boulez kombiniral vrste dinamičnih znamenj $(\mathbf{a}, \mathbf{b}, \mathbf{c}, \mathbf{d})$ z vrstami načinov artikulacije $(\alpha, \beta, \gamma, \delta)$ in kako jih je v obeh delih razporedil med oba klavirja. Tako se dinamika v 12 nizih dela $\mathbf{A}$ v prvem klavirju spreminja po zaporedju, kot ga določa vrsta dinamike $\mathbf{a}$ in v drugem klavirju po zaporedju, kot ga določa vrsta b. V B delu je uporabil še preostali vrsti dinamike. Podobno je urejeno tudi spreminjanje načinov artikulacije. Le-ta se v A delu v prvem klavirju spreminja po zaporedju $\beta$ in v drugem klavirju po zaporedju $\alpha$, $\mathrm{v}$ B delu pa v prvem klavirju po zaporedju $\delta$ in v drugem klavirju po zaporedju $\gamma^{35}$

Ta analiza Boulezovega dela Structures Ia nam omogoča, da lahko govorimo o organizaciji na dveh nivojih oz. o vrstah in iz njih izpeljanih "nadvrstah". Nivo "nižje " organizacije predstavlja ureditev materiala za vse štiri štiri parametre zvoka v vrste s po 12 elementi, nivo "višje" organizacije pa njihovo kombiniranje in končno razvrščanje.

35. Na dve'h mestih v strukturi skladbe se Boulez ne dr • i popolnoma predpisane organizacije in lahko govorimo o "napaki“. Tako se načini artikulacije v $\mathbf{A}$ delu v drugem klavirju spreminjajo po zaporedju 5-5-11-3-12-3-11-12-8-1-8-1, ki se nekoliko razlikuje od zaporedja a (5-5-11-3-12-11-3-12-8-1-8-1). Zamenjal je torej zaporedje artikulacij - (11), - (3) v · (3), - (11). Vendar pa ta menjava ni tako očitna, saj potekata oba niza, $s$ katerima sta povezana načina artikulacije 3 in 11 , istočasno $v$ petem odseku A dela med taktoma 32 in 39. Prav tako je spremenjena v dveh nizih tudi dinamika - glede na zaporedje b bi pričakovali v tem odseku v drugem klavirju, da bosta niza potekala v ffffdinamiki, vendar nam partitura izdaja, da potekata v fffdinamiki (vrsta b torej poteka le nekoliko drugače, kot je mogoče razbrati iz diagonale v transpozicijski tabeli inverzij). Te "napake" pa postanejo še bolj pomenljive, ko vidimo, da se tudi ritmični nizi prav v tem odseku med 32. in 39. taktom ne $\mathrm{dr} \bullet$ e nadrejene ritmične vrste. Permutacije ritmičnih vrst bi se morale v A delu v partu prvega klavirja spreminjati po zaporedju, kot ga določa rakova inverzija na tonu $h$ oz. zapisano s številkami 12-11-9-10-3-6-7-1-2-8-4-5. Zaporedje ritmičnih permutacij $v$ tem delu parta drugega klavirja pa bi v resnici lahko zapisali kot 12-11-9-10-3-6-1-8-2-8-4-5. Zakaj naniza Boulez toliko "napak" prav v enem odseku? Je šlo za trenutno nezbranost ali pa je skladatelj •elel s spremembo dinamike $v$ drugem klavirju le vzpostaviti ravnote $\bullet$ je med obema klavirjema (oba niza v drugem klavirju bi popolnoma preglasila vse ostalo)? To vprašanje se pravzaprav razrašča v dilemo, ali se je Boulez pač zmotil ali pa je namenoma posegel v avtomatizem strukture, da bi bil smiselnejši zvočni rezultat. 


\begin{tabular}{|c|c|c|c|c|c|c|c|}
\hline del & klavir & parameter & $\begin{array}{l}\text { »nižja« } \\
\text { ureditev }\end{array}$ & $\begin{array}{l}\text { št. } \\
\text { elementov }\end{array}$ & & $\begin{array}{l}\text { »višja« } \\
\text { ureditev }\end{array}$ & $\begin{array}{l}\text { št. } \\
\text { elementov }\end{array}$ \\
\hline \multirow[t]{2}{*}{ A } & I & $\begin{array}{l}\text { tonske višine } \\
\text { ritmične vrednosti } \\
\text { dinamika } \\
\text { artikulacija }\end{array}$ & $\begin{array}{l}\text { vsi O } \\
\text { vse RI }\end{array}$ & $\begin{array}{l}12 \times 12 \\
12 \times 12 \\
12 \\
12\end{array}$ & $\begin{array}{l}\text { urejeno kot } \\
\text { urejeno kot } \\
\text { urejeno kot } \\
\text { urejeno kot }\end{array}$ & $\begin{array}{l}\mathrm{I}_{\mathrm{es}} \\
\mathrm{RI}_{\mathrm{h}} \\
\mathrm{a} \\
\boldsymbol{\beta}\end{array}$ & $\begin{array}{l}12 \\
12 \\
1 \\
1\end{array}$ \\
\hline & II & $\begin{array}{l}\text { tonske višine } \\
\text { ritmične vrednosti } \\
\text { dinamika } \\
\text { artikulacija }\end{array}$ & $\begin{array}{l}\text { vse I } \\
\text { vsi RO }\end{array}$ & $\begin{array}{l}12 \times 12 \\
12 \times 12 \\
12 \\
12\end{array}$ & $\begin{array}{l}\text { urejeno kot } \\
\text { urejeno kot } \\
\text { urejeno kot } \\
\text { urejeno kot }\end{array}$ & $\begin{array}{l}\mathrm{O}_{\mathrm{es}} \\
\mathrm{RO}_{\mathrm{s}} \\
\mathrm{b} \\
\alpha\end{array}$ & $\begin{array}{l}12 \\
12 \\
1 \\
1\end{array}$ \\
\hline \multirow[t]{2}{*}{ B } & I & $\begin{array}{l}\text { tonske višine } \\
\text { ritmične vrednosti } \\
\text { dinamika } \\
\text { artikulacija }\end{array}$ & $\begin{array}{l}\text { vse RI } \\
\text { vse I }\end{array}$ & $\begin{array}{l}12 \times 12 \\
12 \times 12 \\
12 \\
12\end{array}$ & $\begin{array}{l}\text { urejeno kot } \\
\text { urejeno kot } \\
\text { urejeno kot } \\
\text { urejeno kot }\end{array}$ & $\begin{array}{l}\mathrm{RI}_{\mathrm{g}} \\
\mathrm{RO}_{\mathrm{h}} \\
\mathrm{c} \\
\delta\end{array}$ & $\begin{array}{l}12 \\
12 \\
1 \\
1\end{array}$ \\
\hline & II & $\begin{array}{l}\text { tonske višine } \\
\text { ritmične vrednosti } \\
\text { dinamika } \\
\text { artikulacija }\end{array}$ & $\begin{array}{l}\text { vsi RO } \\
\text { vsi O }\end{array}$ & $\begin{array}{l}12 \times 12 \\
12 \times 12 \\
12 \\
12\end{array}$ & $\begin{array}{l}\text { urejeno kot } \\
\text { urejeno kot } \\
\text { urejeno kot } \\
\text { urejeno kot }\end{array}$ & $\begin{array}{l}\mathrm{RO}_{\mathrm{h}} \\
\mathrm{RI}_{\mathrm{g}} \\
\mathrm{d} \\
\gamma\end{array}$ & $\begin{array}{l}12 \\
12 \\
1 \\
1\end{array}$ \\
\hline
\end{tabular}

A tudi sama "višja" organizacija se ne kaže kot naključna, temveč kot skrbno premišljena in uravnotežena. To naj potrdi naslednja tabela, v kateri je naznačeno, kako je Boulez iz obeh transpozicijskih tabel "prebral " vrste za "višjo" organizacijo in jih razporedil v obeh delih med oba klavirska parta. 


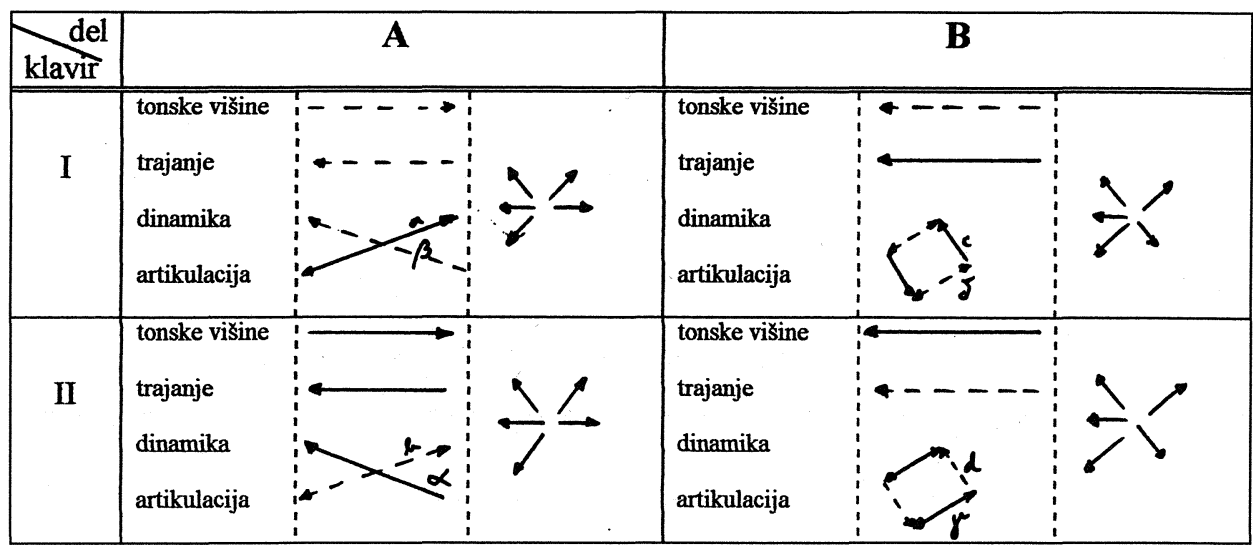

Iz tabele ${ }^{36}$ je tako razvidno, da je Boulez polovico vrst, ki določajo "višjo" obliko kombiniranja ostalih vrst, dobil $\mathrm{v}$ transpozicijski tabeli originalnih vrst in polovico $\mathrm{v}$ transpozicijski tabeli inverzij. Takega ravnotežja pa ne izkazuje razmerje med osnovnimi vrstami (O ali I) in njihovimi rakovimi obrati (RO ali RI), saj je skladatelj za "nadvrste" uporabil dve osnovni vrsti $\left(\mathrm{I}_{\mathrm{es}}, \mathrm{O}_{\mathrm{es}}\right)$, šest rakovih obratov osnovnih vrst $\left(\mathrm{RI}_{\mathrm{h}}, \mathrm{RO}_{\mathrm{g}}, \mathrm{RI}_{\mathrm{g}}\right.$, $\left.\mathrm{RO}_{\mathrm{h}}\right){ }^{37}$ osem vrst pa je izbral $\mathrm{z}$ "diagonalnim branjem" $(\mathbf{a}, \mathbf{b}, \mathbf{c}, \mathbf{d}, \alpha, \beta, \gamma, \delta)$. Nadaljnji Boulezov korak v serialnem razmišljanju kaže "prostorsko "kombiniranje nadvrst, vzetih iz obeh transpozicijskih tabel, saj se smeri branja "nadvrst" za vsak del vsakega izmed obeh klavirskih partov med seboj križajo v štirih smereh (opazovanje tega križanja bi bilo še bolj kompleksno, če bi ga povezali z zgornjimi izsledki o tem, iz katere tabele je bila vzeta posamezna vrsta). Ni se zadovoljil s tem, da je skladbo organiziral le na horizontalni in vertikalni osi - hotel je strukturo kristalne oblike, ki bi jo bilo moč grafično ponazoriti kot nekakšen pravilni šesterokotnik. Ko sta glasbeni material in struktura premišljena in ko so vzpostavljeni vsi vzvodi "višje" in "nižje" organizacije, lahko Boulez v trenutku zapisovanja skladbe določa le še registre tonov dvanajsttonske vrste, gostoto nizov (1-6) in spremembe v tempu (Lent, Très modéré, Modéré, presque vif).

O tem, kako blizu so bila iskanja Pierra Bouleza in Johna Cagea, si lahko potrdimo s kratko analizo Cageove klavirske kompozicije Music of Changes, ki je prav tako nastala leta 1951. Formalno sloni skladba na razmerju $3: 5: 6 \frac{3}{4}: 6 \frac{3}{4}: 5: 3 \frac{1}{8}$ in ima $\left.(29)_{8}\right)^{2}$ taktov (prim. opombo 13). Vendar skladbe ne sestavlja šest delov, kolikor je členov $v$ razmerju, ampak le štirje - posamezni členi razmerja so združeni v en del. Prvi del ima tri enote, drugi $5+6 \frac{3}{4}$ enot, tretji $6 \frac{3}{4}$ enot in zadnji $5+3 \frac{1}{8}$. Opazimo lahko, da je razmerje skoraj simetrično - le zadnjemu členu je še dodana $1 \%$, uravnoteženo pa je zato tudi razmerje med prvima deloma, ki štejeta skupaj 15 enot $(3+5+63 / 4)$ in naslednjima deloma, ki štejeta skupaj 16 enot $\left(6 \frac{3}{4}+5+3 \frac{1}{8}\right)$. Kljub nekoliko drugačni razporeditvi

36 Neprekinjena črta nakazuje, da je Boulez serijo "prebral i iz tabele s transpozicijami originalne dvanajsttonske vrste, črtkana pa, da je vrsta vzeta iz transpozicijske tabele inverzij. Puščica označuje smer branja oz. ali gre za originalno verzijo in inverzijo ali za rakov obrat originalne vrste in rakovo inverzijo.

37 Po dve $\left(\mathrm{RO}_{\mathrm{h}}\right.$ in $\left.\mathrm{RI}_{\mathrm{g}}\right)$ je uporabil dvakrat. 
posameznih enot $\mathrm{v}$ dele ostaja formalna organizacija enaka kot $\mathrm{v}$ nizu predhodnih skladb. Glasbeni material pa je Cage podobno kot Boulez uredil v vrsto tabel..$^{38}$ Vse tabele imajo enotno dimenzijo $8 \times 8$, v njih pa niso urejeni le kompleksi zvokov, temveč tudi ritmične vrednosti, dinamika, spremembe tempa in gostote strukture - skratka vsi parametri zvoka. Tako je izdelal kar 26 različnih tabel -8 za zvoke, 8 za ritmične vrednosti, 8 za dinamiko in po eno za tempe in gostoto.

V osem tabel za zvoke je razporedil vsakič po 32 zvokov (toni, intervali (dva tona), zvočni agregati (kombinacije akordov) in "konstelacije" kot kombinacije posameznih tonov, intervalov in akordov). Teh 32 zvokov je v tabeli razporedil na polja, označena $z$ lihimi številkami, medtem ko so soda polja prazna in označujejo tišino. V tabelah z zvoki je moč najti tudi različne zvočne efekte - pizzicato in glissando po strunah klavirja, različni udarci po ohišju klavirja, ponekod pa je označena že tudi pedalizacija. Vse te različne zvoke naj bi Cage dobil s prosto improvizacijo na klavirju, ${ }^{39} \mathrm{v}$ resnici pa zvočni kompleksi v poljih sledijo dvanajsttonski ureditvi. Tako v vsakem nizu štirih vodoravnih in štirih navpičnih polj uporabi vseh 12 poltonov ene oktave. Zvočni kompleksi torej niso le sistematično urejeni $v$ tabele, ampak je njihova izbira tudi strogo nadzorovana $\mathrm{z}$ dvanajsttonskim principom.

V tabelah z ritmičnimi vrednostmi je zasedenih vseh 64 polj, saj je trajanje pač tisti parameter, ki zaznamuje tako zvoke kot tišino. Ritmični elementi, razporejeni po vseh poljih tabel, pa so precej kompleksni. Sestavljajo jih enostavne ritmične vrednosti v kombinaciji $z$ bolj kompliciranimi vrednostmi, ki jih je Cage dobil $z$ deljenjem večjih vrednosti, pri čemer ni uporabil le potenc števila 2, ampak tudi druga števila (npr. liha števila). Če je Cage komplekse zvokov v tabelah še kontroliral z dvanajsttonsko metodo, pa je pri izbiranju ritmičnih kombinacij že igralo glavno vlogo naključje. Cage si je na igralne karte napisal različne ritmične vrednosti in potem vlekel največ štiri karte ter tako dobil ritmične kombinacije, ki so pogosto zelo kompleksne, pri tem pa jih je včasih še premetal med seboj ali delil z 2 oz. $3 .{ }^{40}$ Prav zato je v notnem zapisu združil tradicionalno notacijo s prostorsko. Za trajanje ene četrtinke je porabil 2,5 centimetra v notnem črtovju. Tak zapis naj bi nekoliko olajšal delo izvajalcu, ki ima pred seboj pogosto nenavadne ritmične kombinacije. Te so pogosto ametrične, težko pa je razlikovati tudi med nekaterimi vrednostmi, ki se v trajanju precej malo razlikujejo (npr.: ! : $\overbrace{}^{7})$.

$\mathrm{V}$ tabelah $\mathrm{z}$ dinamičnimi oznakami je zapolnjeno le vsako četrto polje, pri tem pa Cage kot Boulez uporablja dinamična znamenja v razponu od ppppdo ffff. Zanimivo je, da $\mathrm{v}$ mnogih poljih kombinira po dve oznaki in tako že nakazuje tudi crescendo in

38 Cage sam je tabelarno ureditev glasbenega materiala, ki mu nadomesti lestvico zvokov, s kakršno si je pomagal pri pisanju String Quartet in Four Parts (prim. opombo 23), prvič uporabil v skladbi Concerto for Prepared Piano and Chamber Orchestra. Sestavil je tabelo z 224 polji $(14 \times 16)$ - v 16 vrstic je razporedil inštrumente (flavta, oboa, klarinet, fagot, rog, trobenta, dva trombona, štiri tolkala in štirje parti za godala) in v 14 kolon različne kombinacije zvokov. Zvoke iz tabele je potem izbiral s premikanjem po tabeli: na primer dve polji navzdol, tri polja diagonalno navzdol, štiri polja navzgor. Za nadaljnje delo pa je bil še posebej pomemben postopek, ki ga je Cage uporabil pri pisanju zadnjega stavka tega koncerta. Tu si je prvič pomagal z metanjem treh kovancev, kot ga določa knjiga Ji čing za izbiranje enega izmed 64 heksagramov. S to metodo je sestavil novo tabelo z zvoki ( $\mathrm{z}$ metanjem je določil katere zvoke iz tabel za prejšnja stavka bo prenesel v tabelo za zadnji stavek), z njo pa si je pomagal tudi pri določanju sosledja zvokov in njihovega trajanja.

39 Prim.: Stefan Schädler, Transformationen des Zeitbegriffs in John Cages Music of Changes, v: Heinz Klaus Metzger, Rainer Riehn (ur.), John Cage I, München 1990, str. 185-236.

40 James Pritchet, The Music of John Cage, Cambridge 1993, str. 81. 
decrescendo. Ker je zasedenih le šestnajst polj od štiriinšestdesetih, označujejo prazna polja, da še vedno velja zadnje izžrebano dinamično znamenje.

V tabeli s tempi so $z$ različnimi oznakami tempa zasedena le liha polja, medtem ko so soda prazna in tako ne zahtevajo spremembe tempa. Podobno je tudi s tabelo, ki določa gostoto (koliko zvočnih kompleksov iz osmih različnih tabel bo potekalo hkrati), saj je s števili od 1 do 8 (le-ta označujejo število hkratnih zvočnih kompleksov oz. nizov) zasedeno le vsako osmo polje, prazna pa pomenijo, da se gostota $v$ nadaljevanju ne spreminja.

Cage je tako s 26 tabelami že uredil ves glasbeni material glede na vse parametre zvoka. Pri tem si je pri izbiri zvočnih kompleksov še nekoliko pomagal z dvanajsttonsko tehniko, drug material pa je izbran svobodneje. V naslednjem koraku je moral iz pripravljenih tabel material le še izbrati in ga med seboj povezati. Pri tem je hotel čim bolj omejiti svojo skladateljsko voljo, zato je izbiro podredil naključju. Uporabil je metodo metanja kovancev, kot jo predpisuje kitajska knjiga Ji Čing in s katero si je pomagal že pri pisanju zadnjega stavka Koncerta za preparirani klavir in komorni orkester. Z metanjem kovancev je določil zvočni niz - kombinacijo zvočnega kompleksa, ritmičnih vrednosti in dinamične označbe - kot tudi tempo in gostoto. Najprej je šestkrat vrgel po tri kovance, da je dobil heksagram in z njim številko za ritmično kombinacijo iz tabele. ${ }^{41}$ Potem je postopek ponovil še dvakrat - za zvoke oz. tišino in dinamiko - ter tako dobil niz. Zdaj se je bilo treba še odločiti, koliko nizov bo potekalo naenkrat in kako se bo spreminjal tempo. Ta dva parametra se nista spreminjala $z$ vsako kombinacijo zvočnega kompleksa, ritmične vrednosti in dinamike, pač pa šele $z$ vsakim formalnim odsekom, kot ga je določalo razmerje $3: 5: 6_{4}^{3}: 6_{4}^{3}: 5: 3 \frac{1}{8}$. Tempo in gostoto je določil z meti kovancev takoj na začetku, nato po treh, petih in šestih $\left(6 \frac{3}{4}\right)$ naslednjih taktih itd. Seveda ni nujno, da sta se $z$ vsakim sledečim odsekom tempo in gostota spremenila, saj je izžrebana številka heksagrama lahko določala prazno polje, kar je pomenilo, da parameter še naprej ostaja nespremenjen.

Vendar pa se je Cage zavedal, da bo težko napisati daljšo skladbo le z 256 (32×8) zvočnimi kompleksi, saj bi se le-ti lahko začeli preveč ponavljati in bi tako kmalu dobili vrednost nekakšnih motivov. Zato je uvedel poseben princip izmenjavajoče se statičnosti in mobilnosti - nekatere tabele za zvoke ostajajo "statične ", kar pomeni, da ostajajo zvočni elementi v njih nespremenjeni, druge pa so "mobilne", saj je Cage vsak že uporabljeni zvok takoj nadomestil $\mathrm{z}$ novim. ${ }^{42} \mathrm{~V}$ prvem delu so ves čas statične sode tabele, medtem ko se v lihih tabelah za zvok zvočni elementi menjajo. V drugem delu pa se statičnost in mobilnost izmenjavata med sodimi in lihami tabelami za zvoke v vsaki novi enoti (skupaj je v tem delu 12 enot, kar določa razmerje 5:6 $\frac{3}{4}$ ): v prvi enoti so mobilne spet lihe in statične sode tabele, $v$ drugi enoti so mobilne sode in statične lihe, $v$ tretji enoti so mobilne spet lihe in statične sode itd.

Orisa kompozicijski tehnik obeh skladb - Structures Ia in Music of Changes - nas utrjujeta v spoznanju, da sta bila postopka obeh skladateljev zelo podobna, vendar pa nekatere razlike že tudi kažejo na temeljna razhajanja $v$ poetiki in estetiki obeh sklada-

41 Prim.: John Blofeld, Ji Đing. Knjiga promene, Gornji Milanovac 1985.

42 Prim.: John Cage, To Describe the Process of Composition Used in Music of Changes and Imaginary Landscape No. 4, v: isti, Silence. 
teljev. Boulez je vnaprej jasno uredil ves glasbeni material, saj je določil funkcije oz. serije za vse parametre zvoka. Pri tem si je pomagal s tabelami, kakršne je uporabil že Cage, in celo priznal, da je od prijatelja "prevzel model šahovske deske ${ }^{43}$ Cage poroča Boulezu prvič o tabeli, v katero je uredil material za skladbo, v pismu decembra 1950, ko mu razlaga nastanek Koncerta za preparirani klavir in komorni orkester. ${ }^{44} \mathrm{~V}$ pismu govori tudi že o različnih tabelah, $s$ katerimi bi bilo mogoče definirati vse parametre zvoka. In prav ta ideja Boulezu omogoča, da s pomočjo dveh transpozicijskih tabel uspe "realizirati serialno organizacijo na vseh nivojih “. ${ }^{45}$ V Structures Ia se distribucija vseh parametrov zvoka skriva že v obeh tabelah, podobno pa organizira material za skladbo Music of Changes tudi Cage. A opaziti je nekaj razlik: Boulezu gre očitno za čim bolj jasno, poenoteno strukturo, saj izhaja iz izbrane dvanajsttonske vrste. Le-ta je osnova za obe transpozicijski tabeli s številkami, katerih zaporedje določa tudi vrste $s$ po dvanajstimi elementi za vse druge parametre zvoka. Boulezov koncept gre torej povezovati z njegovo željo po kar se da racionalizirani kristalni strukturi, ki bi izhajala iz enotne ideje in bi skladatelju omogočala popolno kontrolo nad distribucijo vnaprej urejenega glasbenega materiala. Cage pa vseh svojih 26 tabel, v katere je podobno kot Boulez uredil glasbeni material za vse parametre zvoka, poveže $z$ metodo za naključno izbiranje, kakršno poznamo iz knjige Ji Čing. Cage tudi ne izhaja iz izhodiščne ideje (pri Boulezu je to dvanajsttonska vrsta), ki bi jo nato širil, ampak organizira material za vse parametre zvoka svobodneje. Oba skladatelja torej na podoben način uredita glasbeni material za vse parametre zvoka, vendar pa pri njegovi distribuciji v skladbo sledita bistveno drugačnim in v temelju nasprotnim principom. Boulez tudi izbiro materiala oz. vrst nadzoruje $z$ natančno določitvijo "nadvrst", po katerih se vrste za različne parametre družijo v nize, iz katerih se gradi skladba, Cage pa se pri izbiri materiala iz tabel in njegovi distribuciji že prepusti naključju.

Skladateljema se spočetka zdi, da sta skupaj in hkrati prišla do novega postopka. Boulez celo zapiše: "Sva na isti točki raziskav. " ${ }^{46}$ In v resnici "ni bilo nobeno Cageovo delo tako blizu jeziku serialne glasbe «, ${ }^{47}$ saj je do določene mere še vedno vztrajal pri natančni strukturalizaciji, ki je v ureditvi zvočnih agregatov celo dvanajsttonska. Vendar pa so razlike, ki so bile povezane $z$ najosnovnejšimi estetskimi postulati obeh skladateljev, odslej vse bolj nezadržno prihajale na dan. Cage je bil navdušen nad Boulezovimi tabela$\mathrm{mi}^{48}$ bistveno pa se mu je pri tem zdelo, da je tako "moč napisati skladbo, katere kontinuiteta je osvobojena individualnega okusa in spomina ter tudi literature in tradicij umetnosti “. ${ }^{49}$ Boulez decembra 1951 še vedno piše, da v bistvu delata isto, a hkrati že tudi pove, da je "edina stvar [...], ki me ne navdušuje, metoda absolutnega naključja “. ${ }^{50}$ Vdor naključja v skladateljev kompozicijski postopek je bilo za Bouleza nemogoče dejanje, saj je bil prepričan, da mora biti naključje, če do njega že pride, izredno kontrolirano, ker je že v interpolaciji različnih serij oz. glasbenega materiala, organiziranega v tabelah,

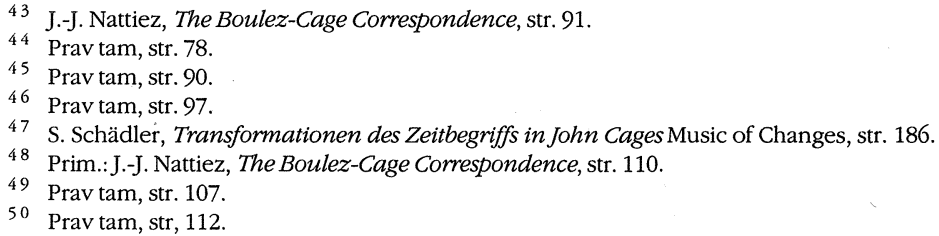


dovolj neznanega. V pismu iz leta 1954 zapiše, da verjetno nikoli ne bo priznal naključja kot komponente zaključenega glasbenega dela. ${ }^{51}$ Podobni konstrukciji, katerih osrednja ideja je bila povezana s tabelarno organizacijo glasbenega materiala za vse parametre zvoka, sta torej dobili popolnoma različne pomene. Boulez je želel poleg tonskih višin serialno nadzorovati še druge parametre zvoka in je "Cageove ideje integriral v zvočni svet, ki se mu je Cage že zdavnaj odpovedal "s2 - medtem ko se je Cage vse bolj bližal naključju, se Boulez ni želel odreči odgovornosti skladatelja. Cage pa je z Music of Changes spoznal, da lahko opusti tudi organizacijo glasbenega materiala, saj je bilo v tej skladbi pravzaprav vse, "kar se je zgodilo, večinoma odvisno le od kovancev, zato tudi struktura ni bila več potrebna ". ${ }^{53}$ Zato je naključje, s katerim si je sprva v Music of Changes pomagal v procesu kompozicije, razširil še na izvedbo, tako da je postal zvočni rezultat skladb in pomen notacije popolnoma nepredvidljiv. Tabele in metanje kovancev so mu pokazale možnost, kako se osvoboditi vsakršne subjektivnosti, saj so si dogodki sledili, ne da bi bili odvisni drug od drugega. Paradoksalno sta prav skladbi, v kateri sta si skladatelja za izhodišče izbrala zelo podoben koncept, v končni fazi pripeljali do popolne ločitve, po kateri Cagea in Bouleza povezujemo z dvema navidez popolnoma nasprotnima tokovoma v glasbi po drugi svetovni vojni. Prav zaradi tega velja premisliti končni zvočni rezultat obeh skladb; lahko podobnosti v načinu organizacije glasbenega materiala in seveda - še bolj pomembno - razlike v njegovi distribuciji zazna uho poslušalca?

Pri analizi Boulezovih Strucures Ia nas morajo še posebej zanimati tisti parametri, ki niso bili zvezani $z$ racionalno urejeno strukturo in jih je skladatelj razporejal prosto, glede na osebno odločitev - gre za register, tempo in gostoto teksture. Že pri opazovanju izbranih registrov pa ugotovimo, da skladatelj ni imel povsem prostih rok, saj se je ves čas skušal izogibati oktavnim ponovitvam tonov - posebej kadar sta se ista tona ponovila kmalu drug za drugim -, z namenom da bi čim bolj oslabil občutek nakakšnih tonalnih središč. ${ }^{54}$ To nas pripelje do repeticij tonov, ki pa so po svoji jakosti različne, kar je odvisno od razdalje med ponovljenima tonoma. Takih repeticij je več, kadar poteka hkrati večje število nizov. Prav zaradi izmikanja ponovitvam tonov v različnih oktavah Boulez ne doseže večjih kontrastov niti $z$ distribucijo tonov v različne registre. To nam potrjuje tudi analiza razporejenosti posameznih tonov $\mathrm{v}$ registre $\mathrm{v}$ posameznih delih skladbe,$^{55}$ saj so enakomerno zasedeni prav vsi registri v vseh delih, od tega pa le nekoliko odstopata X. del, v katerem prevladuje nizki register, in naslednji XI. del s prevladujočimi visokimi toni. Tudi ob večji gostoti nizov Boulez ne uporablja več različnih registrov, kar je povezati s principom izmikanja ponovitvam tonov v oktavah. Tako v V. delu, ko poteka hkrat kar šest različnih nizov, vsak ton kromatične lestvice poveže s točno določenim registrom in uporablja le dvanajst različnih tonskih višin. Največ različnih registrov je zasedenih v XII. in II. delu, ko je dvanajst poltonov razporejenih na 26 oz. 23 različnih višin, pri čemerv obeh primerih potekajo hkrati po štirje nizi, še bolj pomenljivo

51 Prav tam, str. 150. Kako je spremenil svoje mnenje o naključju je razvidno iz njegovega znanega spisa Alea (prim.: Pierre Boulez, Alea, v: Peter Selem (ur.), Novi zvuk. Izbor tekstova o suvremenoj glazbi, Zagreb 1972, str. 15-23).

52 Jean-Jacques Nattiez, Cage and Boulez: a chapter of music history, v: isti, The Boulez-Cage Correspondence, str. 15.

53 J. Cage, Silence, str. 22.

54 Prim.: G. Ligeti, Pierre Boulez.

55 Prim. tabelo v: Paul Griffiths, Boulez, London 1978, str. 23. 
pa je, da je v obeh delih tempo zelo hiter. To pa že kaže na skladateljevo premišljeno kombiniranje različnih "svobodnih" parametrov.

Če razmišljamo o tistih značilnostih, ki skladbo Structures Ia ločijo od Schönbergovih dodekafonskih del, potem se moramo tudi vprašati, ali bi lahko posameznim dvanajsttonskim vrstam pripisali funkcijo tem oz. v kolikšni meri so še nosilke motivično-tematskega dela. Skozi celo skladbo se namreč ponavljajo le transpozicije štirih oblik zaporedja dvanajstih tonov: osnovne dvanajsttonske vrste, inverzije le-te in njunih rakovih obratov. Vendar pa je melodične konture posameznih vrst zelo težko razpoznati, saj je oblika dvanajsttonske vrste vsakič povezana $z$ drugačno ritmično podobo, več vrst poteka hkrati, registri se tako močno spreminjajo, da so intervali med sosednjima tonoma skoraj vedno večji od oktave, kar razbija melodičnost, razpoznavnost posamezne vrste pa je odvisna še od dinamike in artikulacije (ali je oboje dovolj prodorno v primerjavi s sočasno potekajočimi nizi) ter gostote. Končni rezultat je ta, da je posamezno obliko vrste, kljub temu da se vsaka dvanajstkrat ponovi, skoraj nemogoče identificirati. Tako kot je Boulez $s$ preprečevanjem ponovitev tonov $v$ različnih oktavah uničil vsakršna tonalna središča, tako je $s$ konstantnim menjavanjem registrov in ritmične podobe ter s simultanim povezovanjem večjega števila nizov razbil občutek motivično-tematskega dela.

Notranja napetost skladbe in spreminjanje intenzivnosti sta povezani predvsem $z$ gostoto in tempom ter njunim kombiniranjem. Skladatelj je razporedil število nizov, ki potekajo v posameznih delih simultano, povsem svobodno, kot kaže naslednja tabela:

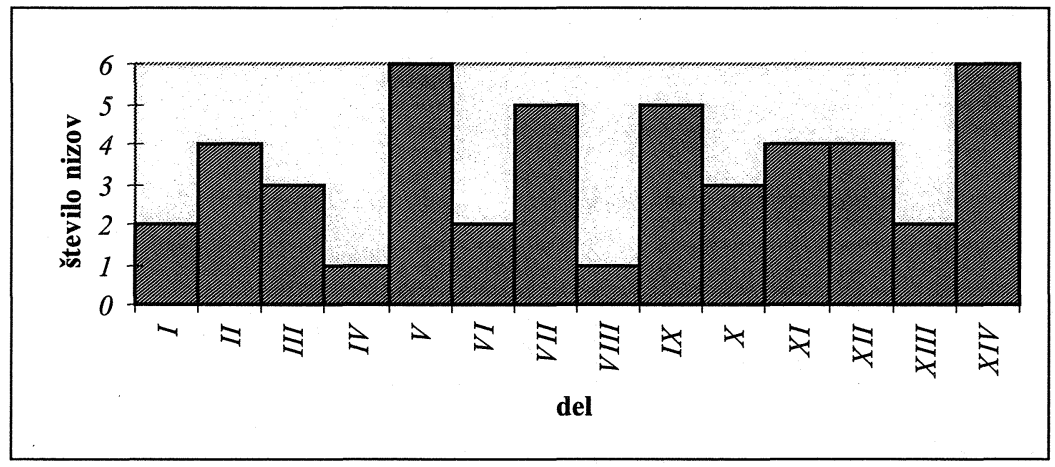

Razporeditev je premišljena, uravnotežena in obenem učinkovita. Tako je na začetku gostota redkejša, na sredini sledijo kontrastne spremembe: $v$ IV. delu je le en niz, temu sledi $s$ šestimi simultanimi nizi najgostejši V. del, potem se gostota zopet razredči (VI. del), pa spet dvigne (VII. del) itd. V drugi polovici so spremembe gostote manjše z izjemo zadnjih dveh delov, ko skladatelj zopet izrablja kontrasten prehod iz dveh simultanih nizov na šest.

Spremembe gostote je nujno opazovati skupaj s spremembami tempa. Boulez uporablja le tri oznake za tempo: Très Modéré $(\delta=120)$, Modére, presque vif $(\delta=144)$ in $\operatorname{Lent}(\boldsymbol{\xi}=120)$, ki jih kombinira skozi celotno skladbo. Spremembe tempa je moč izraziti v razmerju z 10:12:5. Boulez uporablja torej močne, kontrastne spremembe (iz Modére, presque vifv Lent) kot tudi subtilnejše (iz Très Modérév Modére, presque viff), kar kaže naslednja tabela: 
MUZIKOLOŠKI ZBORNIK • MUSICOLOGICAL ANNUAL XXXVII

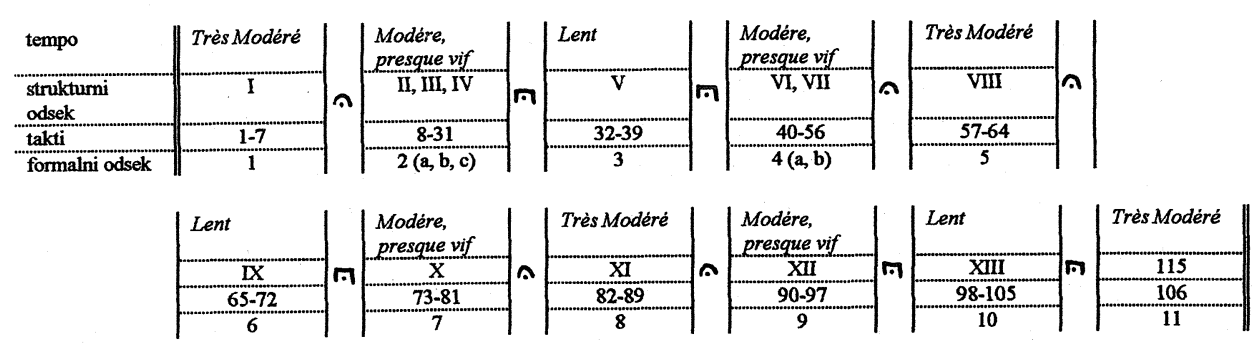

Boulez izkorišča vse možne kombinacije izbranih treh tempov, pri tem pa med spremembe tempa smiselno umešča tudi cezure - kjer je sprememba med tempoma maksimalna (iz Modére, presque vif v Lent), je cezura krajša ( $(\boldsymbol{)})$ in kjer je sprememba minimalna (iz Très Modérév Modére, presque vif), je daljša ( $\cap){ }^{56}$ Tako se izkaže, da je prav povezava med cezurami in spremembami tempa tista, ki odloča o formalni razdelitvi skladbe. Medtem ko smo ugotovili, da se na strukturalnem nivoju spleti serijskih nizov dele v 14 odsekov, pa se tempo spremeni le enajstkrat, vmes pa je temu ustrezno deset cezur, ki lomijo glasbeni tok. Splete serijskih nizov v II., III. in IV. ter VI. in VII. odseku poveže v enotni celoti - spreminja se sicer gostota, ne pa tempo (značilno je, da do takega povezovanja obakrat pride pri najhitrejšem tempu $-z$ lepljenjem posameznih strukturnih odsekov si skladatelj očitno prizadeva za ravnotežje med posameznimi deli). $\mathrm{Na}$ zunanji ravni ima skladba tako enajst delov, pri čemer nekoliko izstopata 2. in 4. del, saj se znotraj njiju gostota spreminja. Končna shema, ki ponazarja kombiniranje svobodnih parametrov kompozicije - registrov, gostote in tempa, je torej taka:
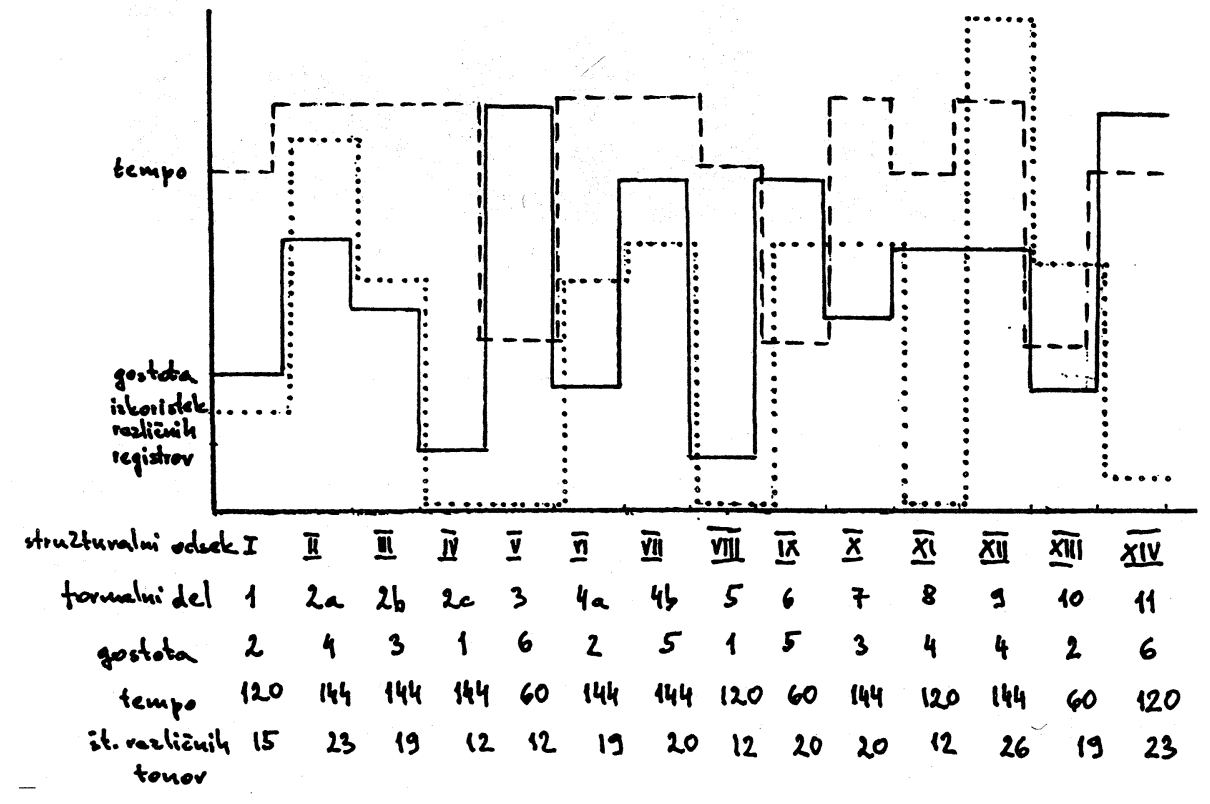

56 Prim.: G. Ligeti, Pierre Boulez. 
Zgornja tabela nam razkriva, kako je Boulez uravnoteženo kombiniral posamezne parametre, tako da prehodi med posameznimi deli niso preveč kontrastni. Na ta način je omejil pomen lastnih odločitev in ga izenačil z rezultati, ki jih je dala premišljena struktura. Prav zato moramo pri razlagi notranjih napetosti v skladbi izhajati predvsem iz zvočne izkušnje - šele v kombinaciji serializiranih in "svobodnih" elementov se kaže pravi karakter skladbe.

Prvi del (1.-7. takt) ima vlogo nekakšne ekspozicije - simultano potekata le dva niza, a v prvem klavirju je zaradi ffffdinamike moč jasno razpoznati osnovno dvanajsttonsko vrsto, medtem ko je zaradi tihe dinamike (quasi $p$ ) manj izstopajoča njena inverzija $\mathrm{v}$ drugem klavirju, ki uvaja predvsem splošni karakter skladbe - neenakomerno utripanje tonov na povsem različnih višinah. Drugi del (8.-32. takt), v katerega so povezani trije strukturni odseki, stopnjuje karakter samega začetka - večja je gostota, tempo je pospešen. Vendar pa se v nadaljevanju vse bolj umirja, saj oba naslednja strukturna odseka prinašata spremembe gostote; a to niso nenadni prehodi (nekoliko je občutiti le spremembo artikulacije), tako da ostaja značaj tega dela enoten. Po tretjem odseku drugega dela, $v$ katerem je jasno predstavljena še inverzija osnovne vrste, saj poteka sama v dinamiki quasi f, sledi kontrastnejši tretji del (32.-39. takt). Največja gostota (hkrati poteka šest nizov) daje temu delu intenzivnost, vendar pa je močan kontrast s prejšnjim delom omiljen, saj je tempo počasen, zaradi večje gostote pa so tudi manj opazne spremembe artikulacije. V četrtem delu (40.-57. takt) sta spet povezana dva strukturna odseka, vendar pa kljub različni gostoti ni slišati med njima jasnejše zareze. Ker je tekstura tega dela na začetku razredčena, artikulacija pa tokatna $(-, s f z)$, je zanj značilen odločen karakter. Ta se nadaljuje tudi v petem delu (57.-65. takt), ko poteka sicer le en niz (osnovna dvanajsttonska vrsta $\mathrm{v}$ prvem klavirju), a zmanjšanje gostote kompenzirata glasna dinamika (ffff) in poudarjena artikulacija (>). Sledi kontrastni šesti del (65.-72. takt), ki ima značilen meditativen karakter: v počasnem tempu (Lent) se križa pet serijskih nizov, ki vsi potekajo v pritajeni dinamiki (dva v $p p$ in po eden $\mathrm{v} p p p p, p p p$ in $m f$ ), kar daje temu delu glede na ostale bistveno drugačen značaj. Sedmi (73.-82. takt), osmi (82.-89. takt) in deveti del (90.-97. takt) so si med seboj precej podobni - skupen je hiter tempo, gostota, raznolika dinamika in točkasta razpršenost zvoka. Slednje še poudarja deseti del (98.-105. takt) - tempo je počasen, vzporedno pa potekata le dva niza, tako da so nastopi posameznih tonov ("točk") le še nekoliko bolj raztegnjeni. Tako nas Boulez pripravlja na končni, enajsti del (106.-115. takt), v katerem se v hitrejšem tempu prepleta šest serijskih nizov v tihi dinamiki - značilna "punktualnost " je prisotna tudi tu, hiter tempo v kombinaciji s pritajeno dinamiko pa daje občutek izgubljanja in zamiranja.

Iz tega kratkega opisa zvočnosti Boulezove skladbe lahko razberemo, da v skladbi ves čas prevladuje neenakomeren utrip povsem izoliranih tonov, ki med seboj niso $\mathrm{v}$ nikakršni povezavi. Tako značilno točkasto zaznavo gre povezovati s konstantnim menjavanjem registrov, hkratnim druženjem več serijskih nizov, ki potekajo v različnih ritmičnih vrednostih, dinamiki in artikulaciji ter v sorazmerno kratkih ritmičnih vrednostih (najdaljša je četrtinka s piko). Taka zvočna podoba je bila očitno skladateljev namen, saj je ohranil prevladujoči zvočni občutek s pomočjo drugih glasbenih parametrov-predvsem tempa v kombinaciji z dinamiko in artikulacijo, ki sta zvezani s serialno ureditvijo - tudi $\mathrm{v}$ delih, kjer poteka hkrati več nizov (gre za tretji, šesti in enajsti del) in se zato ritmično 
pulziranje začne sprevračati v enakomeren utrip dvaintridesetink (prav zato tudi ne kombinira več kot šest nizov naenkrat). Ta zvočnost pa je bistveno nova: Boulez je razbil melodično linijo, se odpovedal motivično-tematskemu delu in enakomerni ritmičnometrični pulzaciji, s kombiniranjem različnih glasbenih parametrov pa tudi ukinil značilne napetostne linije med nižišči in viški (edini izstopajoči del v celi skladbi je meditativni šesti). Težko bi govorili tudi o specifični harmoniji, saj so sozvočja, ki nastajajo, več ali manj splet naključnega sovpadanja tonov iz različnih nizov. Ker se vsi nizi začenjajo hkrati, dobimo najgostejša sozvočja na začetkih posameznih delov. Analiza takih uvodov nas prepriča, da v teh sozvočjih ni najti urejevalnega principa oz. tonalnega središča.

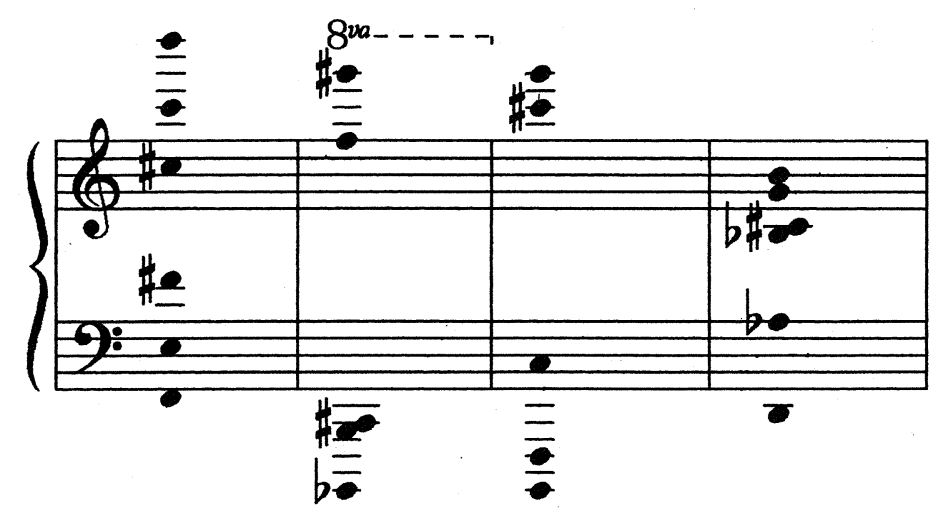

Zgornji primer kaže sozvočja z začetkov V., VII., IX. in XIV. strukturnega odseka največ nam izdaja že prvo sozvočje, v katerem so združeni dvakrat po trije sosednji poltoni ( $e-f$-fis in $c$-cis- $d$ ). Akord ni grajen niti terčno niti po kakem drugem sistemu, je le rezultat sovpadanja šestih različnih serijskih nizov. Razpršenost tonov po različnih registrih nam tudi onemogoča, da bi razločevali med harmonsko "spremljavo" in melodijo. Tradicionalni glasbeni elementi so eliminirani in namesto njih se uveljavljajo novi. Prav zato dobiva racionalno organizirana serialna struktura dvojen pomen: na eni strani je Boulez z njo razbil tradicionalne glasbene parametre (harmonija, melodija, motivičnotematsko delo, metrično-ritmični impulz, oblika z viški in nižišči), po drugi strani pa razvil nov kompleksni sistem, s katerim je stare kategorije zamenjal z novimi: gostoto, razpršenostjo, hitrostjo in njihovimi spremembami.

Ali nam daje analiza Cageovega dela drugačne rezultate? Music of Changes sestavljajo štirje deli, vendar pa gre bolj za abstraktno delitev, povezano $\mathrm{z}$ razmerjem $3: 5: 63{ }_{4}: 63 / 4: 5: 3^{1} /$, na katerem sloni formalna zasnova skladbe, sam glasbeni tok pa je drugače brez zarez in zaustavitev, zato ob poslušanju ne moremo ugotoviti, v katerem trenutku je nastopil nov formalni odsek skladbe. Music of Changes, zaigrana od začetka do konca brez premorov, se zdi poslušalcu napisana v enem stavku, katerega enoviti glasbeni tok tu in tam poživljajo spremembe $\mathrm{v}$ gostoti in tempu. Skladba je $\mathrm{v}$ resnici formalno zelo jasno koncipirana; štirje deli se še nadalje dele v 29 odsekov, ti pa so sestavljeni še iz krajših formalnih enot, ki štejejo po $3,5,6 \frac{3}{4}$ ali $3 \frac{1}{8}$ taktov. Na zvočnem nivoju so razlike med štirimi glavnimi deli zelo majhne - še najbolj očitno so različne 
dolžine posameznih delov: prvi traja 4 minute in pol, drugi približno 19 minut, tretji in četrti pa vsak po 11 minut. Vse druge značilnosti posameznih delov pa so že v veliki meri odvisne od naključja, ki določa spremembo gostote, tempa in ostalih parametrov zvoka. Prvi del je najbolj razgiban in energičen, v drugem imamo že daljše odseke tišine (npr. med 54. in 62. taktom ter med 226. in 235. taktom), ki trajajo tudi več kot 20 sekund, poleg posameznih tonov, zvočnih agregatov in zapletenejših zvočnih sklopov pa Cage $\mathrm{v}$ tem delu uporablja tudi več drugih zvočnih efektov (igranje po strunah, glissando po strunah, različni udarci po ohišju klavirja ipd.). Tretji del prinaša še več tišine (srečamo jo že na samem začetku), zelo počasni pa so tudi tempi, saj prevladujejo oznake $\mathbf{d} 63,80$, $52,60,72,84,92$, le v šestih taktih pa znaša tempo 184 četrtink na minuto. V zadnjem delu je dolgih pavz nekoliko manj, izžrebani tempi pa so še vedno v veliki meri počasni.

Za natančnejšo analizo izberimo najhitrejši prvi del, v katerem je najmanj odsekov popolne tišine in je glasbeni stavek najbolj razgiban in kontrasten. Kratki prvi del obsega le tri enote, ki se nadalje delijo v skupine po 3, 5, 63/ $, 63 /{ }_{4}, 5$ in $3 \frac{1}{8}$ taktov (skupaj šteje torej $3 \times\left(3+5+63 /{ }_{4}+6^{3} /{ }_{4}+5+3 \frac{1}{8}\right)=3 \times 29{ }_{8} / 8=587 /$ taktov $)$. Z vsako tako novo skupino je Cage s pomočjo treh kovancev in izdelanih tabel na novo določil gostoto in tempo, ki pa se nista nujno spremenila, saj so bila nekatera polja v tabelah prazna in tako niso označevala spremembe. Prav ta princip zapleta formalno podobo skladbe, saj ne prihaja vedno do kontrastnih prelomov - lahko se spremeni tempo, gostota pa ostaja nespremenjena; lahko je sprememba obojega minimalna ipd. Kombinacija sprememb gostote in tempa v vsakem formalnem odseku odloča torej o zunanji oblikovanosti skladbe.

\begin{tabular}{|c|c|c|c|c|c|c|c|c|c|c|c|c|c|c|c|c|c|c|}
\hline del & & & & & & & & & & 2 & & & & & 3 & & & \\
\hline takti & 3 & 5 & 6 & 6 & 5 & 3 & 3 & 5 & 6 & 6 & 5 & 3 & 3 & 5 & 6 & 6 & 5 & 3 \\
\hline tempo & 69 & 176 & 100 & 100 & 100 & 58 & 58 & 58 & 76 & 76 & 108 & 108 & 108 & 108 & 184 & 184 & 184 & 63 \\
\hline relativna gostota ${ }^{34}$ & 2 & 1 & 2 & 1 & 1 & 1 & 3 & 2 & 3 & 2 & 1 & 2 & 2 & 3 & 3 & 2 & 1 & 2 \\
\hline $\begin{array}{l}\text { povezave glede } \\
\text { na tempo }\end{array}$ & $\varpi$ & $\square$ & 4 & 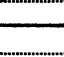 & $\longrightarrow$ & $L$ & & & & 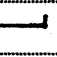 & & & & & & & - & 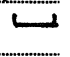 \\
\hline $\begin{array}{l}\text { povezave glede } \\
\text { na gostoto }\end{array}$ & $\omega$ & $山$ & Ш & & & & & & & $\longrightarrow$ & 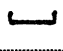 & & & & & 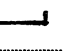 & $山$ & $\sqcup$ \\
\hline $\begin{array}{l}\text { formalna delitev } \\
\text { po zvocnem visu }\end{array}$ & & & $山$ & & & & & & & & & & & & & & $山$ & $山$ \\
\hline
\end{tabular}

Zgornja razpredelnica nam kaže, kako spremembe tempa ne sovpadajo s spremembami gostote, oboje pa tudi ni povezano s tremi velikimi deli, ločenimi med seboj $z$ dvema taktnicama. Šele kombiniranje obojega daje formalno podobo, kot jo kaže zadnja vrstica v primeru, narejena na podlagi slušnega vtisa, ki je upošteval spremembe gostote in tempa. A tako drobljenje skladbe je nasilno, saj v resnici poteka v enem zamahu, vsakokratne spremembe pa ne prinašajo bistvenih kontrastov. Zato tudi ne moremo govoriti o nižiščih ali viških, kljub jasni formalni členitvi (določa jo razmerje) pa je razbita klasična periodičnost in vsakršen občutek natančne strukturiranosti. Podobno je razbit metrično-ritmični utrip, saj Cage uporablja najrazličnejše ritmične vrednosti, njihovo kombiniranje pa je bilo podvrženo naključnemu izbiranju - taktnice imajo tako v resnici le orientacijsko vrednost.

57 Naknadno določevanje gostote (število zvočnih nizov, ki potekajo istočasno) je praktično nemogoče, zato smo označili relativno gostoto s številkami od 1 do 3 ; 1 za redko teksturo, 2 za srednje gosto in 3 za zelo gosto. 
V prvem delu je Cage izbiral zvoke iz štirih mobilnih tabel in štirih statičnih tabel. Prav zaradi slednjih se moramo vprašati, ali je mogoče, da bi kak muzikalno bolj izrazit zvočni kompleks iz štirih statičnih tabel prevzel vlogo motiva. Vendar pa je večina le-teh neizrazita, gre predvsem za zvočne agregate, ki se v zvočnem toku ne razvijajo, razdalje med njihovimi ponovitvami in kontekst, v katerem vsakič nastopajo (gostota, tempo, sočasni zvočni nizi, dinamika), pa nam onemogočajo, da bi si jih zapomnili.
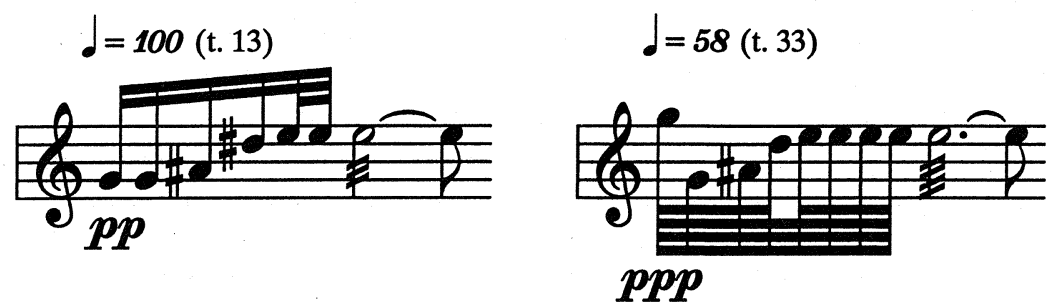

Tako prepoznamo ponovitev bolj razvejanega kompleksa, ki ga še posebej karakterizirajo hitre repeticije (gl. zgornji primer), posebej nenavadna pa je zaporedna ponovitev zvočnega kompleksa v 38. taktu, ki pa je zgolj produkt naključja:

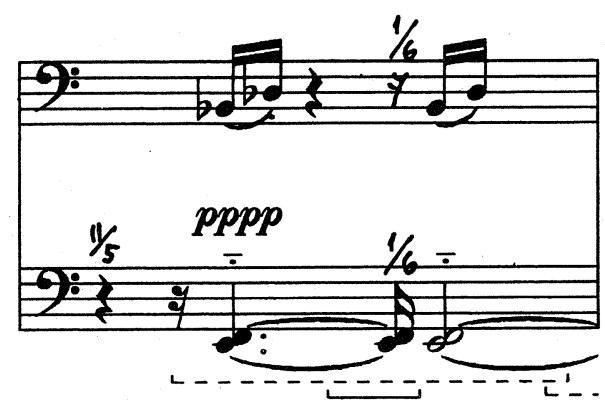

Ob poslušanju skladbe se nam taka ponovitev zdi šokantna, kar nas le še utrjuje v prepričanju, da v Music of Changes ni več pravega motivično-tematskega dela. To pa velja tudi za melodiko. Posamezne komplekse je izbral skladatelj sam in nekateri-taki bolj razširjeni, ki niso sestavljeni le iz posameznih tonov oz. sozvočij-izkazujejo melodično logiko (imajo izrazito smer gibanja, specifični melodični lok ali logičen zaključek), vendar pa se te značilnosti v kombinaciji več kompleksov drug za drugim ter drug na drugem izgubljajo. Tako so značilne hitre spremembe registrov, načina artikulacije, jakosti in ritmičnega utripa, kar slabi občutek melodične linije in vse skupaj se sprevrača v neenakomeren utrip tonov, posejanih na najrazličnejše tonske višine. V tabelah so zvočni kompleksi sicer še urejeni $z$ dvanajsttonsko tehniko, a je $z$ naključno izbiro zvočnih kompleksov tudi učinek tega principa oslabljen. Isto velja tudi za harmonijo - če so posamični zvočni kompleksi v tabelah še koncipirani tradicionalno (srečamo tudi terčna sozvočja), pa se v kombiniranju različnih zvočnih nizov njihove karakteristike izgubljajo, klasični akordi pa nimajo več svojih funkcij. Cage je bil prepričan, da je z Music of Changes ustvaril kompozicijo, ki se bistveno razlikuje od tradicionalnega glasbenega 


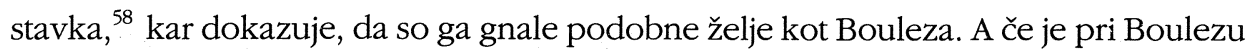
povsem nov glasbeni stavek posledica racionalno organizirane serialne strukture, se to pri Cageu ne zgodi toliko zaradi glasbenega materiala, organiziranega $v$ tabele - ta je lahko sam na sebi še celo tradicionalen - temveč zaradi vključitve naključja.

Končni rezultat je torej podoben kot pri Boulezu - ne moremo več govoriti o harmoniji ali melodiji, glasbeni stavek se spreminja v neenakomerno utripanje najrazličnejših tonskih višin. Prepoznati ni tudi struktur (motivov), ki bi se ponavljale. Odločilno vlogo očitno prevzame spreminjanje gostote teksture. "Najbolj značilna spremeba v Music of Changes je sprememba gostote ", ${ }^{59}$ tej pa se pridružuje spreminjanje tempa, ki v resnici pripomore $\mathrm{k}$ zgoščevanju teksture. $\mathrm{K}$ temu, da se posamezni toni začno spreminjati $\mathrm{v}$ točke, pa doda svoje tudi konstantno spreminjanje dinamike, ki je še posebno izstopajoče na zelo gostih mestih. Tradicionalni glasbeni parametri-melodija, harmonija, metrum, motiv - se umikajo novemu inštrumentariju; pomembne postanejo fizikalne lastnosti zvoka (frekvenca, jakost, gostota, hitrost ipd.) in bolj kot kdaj koli poprej je jasno, da se glasba odvija v prostoru in času.

Iz kratkih analiz in opisa zvočnosti Boulezove in Cageove skladbe so razvidne vse podobnosti pa tudi razlike med deloma. Medtem ko je glasbeni material organiziran na skoraj identičen način, je bistveno drugačen postopek povezovanja izbranega materiala v zvočno tkivo (pri Boulezu stroga serialnost, pri Cageu že naključje). Zanimati pa nas mora končni rezultat dela obeh skladateljev, ki se kaže v zvočnosti njunih sḳ̣adb. Analiza slednje nas utrjuje v spoznanju, da obe skladbi zvenita precej podobno. Slišimo lahko vrsto med seboj nepovezanih tonov, razpršenih v širokem ambitus, brez razločnega metričnega impulza v konstantnem, večkrat tudi skrajno kontrastnem menjavanju dinamike, zato je nemogoče iskati osnovne prvine tradicionalnega glasbenega stavka: melodijo - ni jasno, kateri toni naj bi bili nadrejeni in bolj pomembni, harmonijo - naključno sozvenenje tonov ni vpeto $v$ procesualno harmonsko logiko, enakomeren in razpoznaven ritmično-metrični pulz je zabrisan, formalno ogrodje pa se ne naslanja več na motivično-tematsko delo (toni niso urejeni v skupine, ki bi bile prepoznavne in bi se v spremenjeni ali nespremenjeni obliki ponavljale) ali na vpetost glasbenega toka med vrhove in nižišča, temveč je veliko bolj odvisno od fizikalnih parametrov zvoka in njihovega spreminjanja - od gostote teksture, povprečne jakosti in frekvence posameznega odseka in števila glasbenih dogodkov na časovno enoto. Vprašati se moramo, kako je mogoče, da sta skladatelja prišla do tako zelo podobnih rezultatov s pomočjo, vsaj v osnovi diametralno nasprotujočih si konceptov. Delni odgovor verjetno leži v dejstvu, da se skladatelju komponiranje s skrbno premišljeno in vnaprej pripravljeno serialno strukturo, urejeno v mrežo vrst in "nadvrst", ki nadzorujejo distribucijo vrst v skladbo, spreminja $v$ slepi avtomatizem, pri katerem ima nad končno podobo skladbe prav tako malo nadzora kot skladatelj, ki se prepusti naključju. Predeterminirana struktura in igra $\mathrm{z}$ naključjem dajeta očitno zelo podobne razultate.

Bolj kot ta ugotovitev in uganka, kaj imata skupnega skrajni red in navidezni kaos, ${ }^{60}$ pa je pomembno, da delo obeh skladateljev postavimo v zgodovinski kontekst - skladbi

58 Prim.: J. Cage, To Describe the Process of Composition Used in Music of Changes and Imaginary Landscape No. 4, str. 59.

59 J. Pritchet, The Music of John Cage, str. 88.

60 Prim.: Otto Kolleritsch (ur.), Musikalische Gestaltung im Spannugsfeld von Chaos und Ordnung, Dunaj, Gradec 1991. 
sta vendarle nastali v istem letu (1951) in tako pričata o posebnem stanju glasbenega materiala in kompozicijske tehnike takoj po drugi svetovni vojni. Željo obeh skladateljev po vzpostavitvi povsem novega glasbenega jezika je tako gotovo moč povezovati s t.i. "točko nič", ki je pri tem igrala dvojno vlogo: vojna je bila pomemben zgodovinski mejnik, ki je postavil vrsto etičnih vprašanj, zaradi katerih nihče ni želel obujati duha časa, $v$ katerem je na oblast lahko prišla nacistična ideologija, na drugi strani pa je prav dolgoletna izolacija kot posledica vojne omogočila lažjo prekinitev s tradicijo. Ta korak pa vendarle ni bil tako enostaven, kar nam kažeta tudi obe "poti ${ }^{61}$ - Boulezova in Cageova. Oba sta se namreč morala za trenutek popolnoma odreči lastni subjektivnosti (skrajna serializacija in komponiranje $z$ naključjem bistveno zmanjšujeta pomen avtorjevih odločitev za končno zvočno podobo) - šele tako sta lahko ušla močni senci tradicije in preteklosti. Kako radikalna je bila ta odpoved nam kaže tudi glasbeni material, ki ga je Boulez izbral za svojo skladbo Structures Ia-dvanajsttonsko vrsto in ureditev ritmičnih vrednosti je namreč prevzel iz Messiaenove skladbe Mode de valeurs et d'intensités. Sam Boulez razlaga, da na začetku iskanja povsem novega glasbenega jezika "ni želel delovati sam" ${ }^{62}$ zato je izključil kar največ osebnih odločitev, ki bi izdajale njegov subjektivni okus in nagnjenja. Podobni "objektivistični" razlogi so ga vodili tudi pri izbiri inštrumenta ${ }^{63}$ abstraktne ideje naj bi bilo mogoče uresničiti le v inštrumentalnem mediju, pri čemer se klavir še "najmanj upira ekstremnim uporabam" " ${ }^{64}$ saj zveni v vseh registrih enako dobro in izenačeno. Pri izbiri ga torej ni vodila zvočna barva inštrumenta ali njegove kvalitete, pač pa pragmatično spoznanje, da ima še najmanj napak.

V tej luči pa je potrebno obema skladbama priznati posebno dokumentarno vrednost, ki jo samo še potrjujejo spoznanja naslednjih generacij skladateljev, pa čeprav so večkrat ubrali pot, ki je bila bistveno drugačna od totalne serializacije ali naključja. Očitna je namreč postala razpoka med determinacijo in svobodo - serialisti so spoznali, da je s poudarjanjem posameznih elementov postajala zabrisana celota. ${ }^{65}$ Zato so pričeli razmišljati bolj globalno - pomembni niso bili več posamezni toni, ki so do zdaj dajali značilne punktualne razsežnosti, temveč zvočna barva in tekstura kot posledici zlitja izoliranih tonov v enotni efekt, skladateljevo delo pa je tako postalo podobno slikarjevemu in glasbeni proces kolažu barv in ploskev. "Zvočne kompozicije " ${ }^{66}$ so imele torej svoj izvor v serialnih in aleatoričnih skladbah; pomembni sta postala akustika in zvok, ne pa več melodija, ritem, kontrapunkt ali posamezni parametri, kot je bilo to še pri serialistih. Nekaj podobnega je s svojo "statistično formo" nakazal že K. Stockhausen, še pomembnejše korake v to smer sta storila K. Penderecki in G. Ligeti, posebej poučna pa je izkušnja W. Lutosławskega, ki naj bi prav s poslušanjem Cageovega Concert for Piano and Orchestra prišel do spoznanja, da lahko kompozicijski proces začne pri kaosu, ki ga

61 Prim.: Hans Rudolf Zeller, Von einer (zeitweiligen) Korrespondenz, v: H.-K. Metzger, R. Riehn (ur.), Pierre Boulez, str. 164.

62 Pierre Boulez, Musikdenken heute 2, Mainz 1985, str. 41.

63 Zanimivo je, da so klavir izbrali za prve skladbe skoraj vsi serialisti-Boulez, Stockhausen (Klavierstück I), Messiaen (Mode de valeurs et d'intensités), Goeyvaerts, pri nas Srebotnjak in Ramovš - za klavir je napisana skladba Music of Changes, tudi Schönberg pa je prva dodekafonska dela napisal za isti inštrument.

64 P. Boulez, Musikdenken heute 2, str. 42.

65 Prim.: György Ligeti, Wandlungen der musikalischen Form, v: Die Reihe 7, Dunaj 1960, str. 5-7.

66 Gl.: Hermann Danuser, Die Musik des 20.Jahrhunderts, Laaber 1984, str. 373-391. 
kasneje ureja - za celoto ni potrebna jasna determinacija vsakega detajla. ${ }^{67} \mathrm{Na}$ podlagi tega spoznanja je razvil svoj tip aleatorike, pri kateri pa izvajalec še zdaleč nima tako prostih rok kot pri Cageovih poznejših skladbah.

Kakršenkoli je že naš odnos do včasih precej abstraktne serialne glasbe Bouleza in Cageovega vključevanja naključja v kompozicijski in izvajalski proces, pa je potrebno kompozicjski razvoj obeh skladateljev, ki je, kakor nam potrjuje njuna korespondenca, ${ }^{68}$ nekaj časa potekal vzporedno, razumeti kot nujno fazo v razvoju glasbene umetnosti. Če je naslednja generacija skladateljev zaobšla obe skrajnosti - naključje so spretno kontrolirali (npr. glasba W. Lutoslawskega), serije so postale zgolj pripomoček in se niso več razraščale v kompleksno totalno organizacijo, pa tega ne gre razumeti kot korak "nazaj". Spoznanj, ki sta jih prinesli stroga serializacija in Cageova aleatorika, ni bilo več mogoče zaobiti: glasbena govorica je bila odvisna od interakcije gostote, hitrosti, jakosti, registra in drugih lastnosti zvoka. Mislilo se je torej v novih glasbenih kategorijah, ki so postale pomembne prav s Cageovimi in Boulezovimi kompozicijami. Njune inovacije je nova generacija integrirala $\mathrm{v}$ zaokrožena umetniška dela, ki se $\mathrm{z}$ večjim deležem avtorjeve kontrole niso izmikale osebnemu izrazu. ${ }^{69}$

67 Cit. po S. Stucky, Lutostawski and his Music, Cambridge 1981, str. 84.

68 Prim.: J.-J. Nattiez, The Boulez-Cage Correspondence.

69 H. Danuser, Die Musik des 20. Jahrhunderts, str. 380, 381. 